\title{
A conspectus of Combretum (Combretaceae) in southern Africa, with taxonomic and nomenclatural notes on species and sections
}

\author{
M. JORDAAN*广, A.E. VAN WYK** and O. MAURIN***
}

Keywords: Combretaceae, Combretum Loefl., lectotypification, phylogeny, sections, southern Africa, taxonomy

\author{
ABSTRACT
}

\begin{abstract}
Two subgenera of Combretum Loefl. occur in the Flora of southern Africa (FSA) region. Previous sectional classifications were assessed in view of molecular evidence and accordingly modified. Ten sections in subgen. Combretum, 25 species and eight subspecies are recognized. Subgen. Cacoucia (Aubl.) Exell \& Stace comprises four sections and seven species. $C$. engleri Schinz, C. paniculatum Vent. and C. temuipes Engl. \& Diels are reinstated as distinct species separate from C. schumannii Engl., C. microphyllum Klotzsch and C. padoides Engl. \& Diels, respectively. C. schumannii occurs outside the FSA region. Records of $C$. adenogonium Steud. ex A.Rich., C. platypetalum Welw. ex M.A.Lawson subsp. oatesii (Rolfe) Exell and subsp. baumii (Engl. \& Gilg) Exell in Botswana are doubtful. C. celastroides Welw. ex M.A.Lawson subsp. orientale Exell is elevated to species level as C. patelliforme Engl. \& Diels. C. grandifolium F.Hoffm. is reduced to C. psidioides Welw. subsp. grandifolium (F.Hoffm.) Jordaan. Twenty-six names are lectotypified. The type, a full synonymy, other nomenclatural and taxonomic information, the full distribution range and a distribution map are provided for each taxon. Selected specimens examined are given for poorly known species. Keys to subgenera, sections and species are provided.
\end{abstract}

\section{CONTENTS}

Abstract

Introduction

Materials and method ................ 136

Taxonomy ........................ 136

Key to the southern African subgenera of Combretum 136

A. Combretum Loefl. subgen. Combretum .... . . . 137

Key to sections of subgen. Combretum in FSA

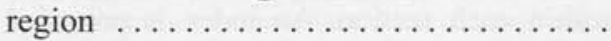

Group $1(\mathrm{I}-\mathrm{V}) \ldots \ldots \ldots \ldots \ldots \ldots \ldots \ldots \ldots \ldots \ldots \ldots \ldots$

I. Combretum sect. Angustimarginata ....... 137

Key to species of sect. Angustimarginata ... 138

II. Combretum sect. Spathulipetala ... . . . . . . 141

Key to species of sect. Spathulipetala ...... 141

III. Combretum sect. Macrostigmatea ... . . . . 142

IV. Combretum sect. Glabripetala .......... 143

V. Combretum sect. Ciliatipetala ........... 143

Key to species of sect. Ciliatipetala ....... 144

Group 2 (VI-X) . . . . . . . . . . . . . . . . 147

VI. Combretum sect. Hypocrateropsis .... . . . . 147

Key to species of sect. Hypocrateropsis . . . 148

VII. Combretum sect. Metallicum ... . . . . . . . 149 Key to subspp. of Combretum collinum ... 149

VIII. Combretum sect. Breviramea ......... 151

IX. Combretum sect. Campestria ......... 151

X. Combretum sect. Plumbea ........... 152

B. Combretum subgen. Cacoucia ........... 152

Key to sections of subgen. Cacoucia ....... 152

XI. Combretum sect. Poivrea .............. 153

XII. Combretum sect. Conniventia ......... 153

XIII. Combretum sect. Megalantherum ........ 155

XIV. Combretum sect. Oxystachya ........ 155

Specimens examined ................ 155

* National Herbarium, South African National Biodiversity Institute, Private Bag X101, 0001 Pretoria. † Student affiliation: Department of Plant Science, University of Pretoria, 0002 Pretoria.

** H.G.W.J. Schweickerdt Herbarium, Department of Plant Science, University of Pretoria, 0002 Pretoria.

**** Molecular Systematics Laboratory, Department of Botany and Plant Biotechnology, APK Campus, University of Johannesburg, P.O. Box 524, 2006 Auckland Park, Johannesburg.

MS, received: 2009-09-17.
Acknowledgements ................ 156

References ..................... 156

Index ...................... 158

\section{INTRODUCTION}

Combretum Loefl. belongs to Combretaceae, one of the 14 core families of the Myrtales (Dahlgren \& Thorne 1984; Sytsma et al. 2004), one that is characterized by mainly opposite leaves and the absence of stipules or stipules being rudimentary (Stace 2007). Combretaceae is sister to all the other 13 families combined, and diverged early in the evolution of the Myrtales (Angiosperm Phylogeny website-APweb). Combretum (excluding Quisqualis L.) comprises about 250 species (Bredenkamp 2000 ) and occurs in tropical and subtropical regions (America, Africa, Madagascar, India, Asia, Malesia, Australia), but is absent from the Pacific Islands (Stace 2007). Although Bredenkamp (2000) gives the distribution as excluding Australia, C. trifoliatum Vent., a vigorous woody climber, was discovered in northern Australia in the 1980s (Clarkson \& Hyland 1986; Pedley 1990). The greatest species diversity occurs in Africa, namely 163 in sub-Saharan Africa (Klopper et al. 2006), with 43 in Gabon (Jongkind 1999), 36 in Cameroon (Liben 1983), and about 30 in southern Africa (Jordaan 2003). It is widespread in the FSA region in all countries and provinces, except in the Free State (rare), Lesotho and Western Cape (Bredenkamp 2000).

Members of Combretum are mostly deciduous or semi-deciduous (rarely evergreen) trees, shrubs, scandent shrubs (scramblers), subshrubs with woody rootstocks (so-called geoxylic suffrutices; rare in southern Africa) or woody climbers (lianas), sometimes with spine-tipped lateral shoots (C. imberbe Wawra). Bark on young stems is often flaking and peeling in stringy strips or threads in most species or in large \pm cylindrical or hemicylindrical pieces revealing an exposed cinnamon-red surface (C. psidioides group). Leaves are opposite, subopposite (or locally alternate), sometimes 3 - or 4-whorled, exstipulate, simple and the margins are 
always entire, rarely crenulate, or sometimes undulate (C. elaeagnoides Klotzsch, $C$. petrophilum Retief and $C$. tenuipes Engl. \& Diels). Indumentum on leaves, flowers and fruit consists of unicellular, compartmented or combretaceous hairs (sharp-pointed, thick-walled with a bulbous base), multicellular stalked glands and multicellular scales. Mature scales can be classified into three major groups and have proved to be important in assessing taxon boundaries and phylogenetic relationships (Exell \& Stace 1972). Leaves are pinnately veined where the lateral veins are arranged parallel to each other, somewhat spaced and looping before they reach the margin (brochidodromous). Hair-tuft domatia (marsupiiform) in the axils of the veins below are present in a number of species (Stace 1965). Bases of leaf petioles may persist as straight spines or recurved hooks as in C. bracteosum (Hochst.) Brandis, C. mossambicense (Klotzsch) Engl. and C. microphyllum Klotzsch. Flowers are bisexual and are borne in axillary or terminal branched or unbranched spikes, sometimes subcapitate, and are bracteate. Flowers are 4- or 5-merous and usually sweetly scented. Petals vary from white, creamcoloured, yellow, yellow-green in most species, but are sometimes pale to deep pink or bright red as in $C$. bracteosum, C. microphyllum, C. paniculatum Vent., $C$. platypetalum Welw. ex M.A.Lawson and C. wattii Exell. In deciduous species, the flowers appear before or with the new leaves, e.g. C. elaeagnoides Klotzsch, C. microphyllum, C. platypetalum, C. psidioides and C. zeyheri Sond. The calyx is produced into a short, campanulate or cup-shaped limb above the inferior ovary. Stamens are inserted on the hypanthium, usually twice as many as the sepals or petals, and usually exserted beyond the petals. The stamens vary in colour from yellow, orange, pinkish, crimson or reddish to red-brown. A glabrous or pilose, green or red, well-developed nectariferous disc is often present at the base of the upper hypanthium. Nectar production is indicative of flowers that are pollinated by a wide range of insects or birds (Stace 2007). The ovary is inferior and 1-locular with two pendulous anatropous ovules of which only one develops into a seed. The fruit is glabrous or covered with scales and/or hairs and is mainly a 4-winged, or occasionally 5 -winged $(C$. mossambicense, $C$. oxystachyum, $C$. wattii) indehiscent samara, except in $C$. bracteosum which has wingless fruit (nuts). In most cases winged fruit are wind-dispersed and the wingless fruit seem to be an adaptation to water dispersal (Exell \& Stace 1972).

Despite extensive taxonomical and anatomical studies on Combretum in tropical and southern Africa by Engler \& Diels (1899), Dümmer (1913), Stace (1961; $1965 ; 1969 ; 1980 ; 1981)$, Exell $(1968 ; 1978)$, Verhoeven \& Van der Schijff (1973), Wickens (1973), Van Wyk (1984), Carr (1988), Rodman (1990) and Tilney (2002), there are still taxonomic and nomenclatural problems remaining, as well as new taxa to be described. Some names are misapplied and the identity of some taxa in southern African herbaria is uncertain. Recent molecular work (Maurin et al. 2010) has indicated that taxa boundaries need revising to reflect more accurately the phylogeny of Combretum and its allies. Maurin et al. (2010) deal mostly with the subgeneric, sectional and generic delimitation of Combretum, whereas the present paper deals with species delimitation, the status elevation of infraspecific taxa and lectotypification of some names.

\section{MATERIALS AND METHOD}

All material of Combretum in the National Herbarium, Pretoria (PRE) and H.G.W.J Schweickerdt Herbarium, University of Pretoria (PRU) was examined. Two websites were consulted for type material: 1, www. aluka.org and 2, the Zürich Herbarium: www.zuerichherbarien.unizh.ch. Types seen electronically are cited as e! Where the holotype was destroyed in the Berlin Herbarium (B) during World War II, lectotypification is covered by Article 9.15 of the Code (McNeill et al. 2006) which provides for narrowing the lectotype to a single specimen. Acronyms of herbaria where types are housed follow Holmgren et al. (1990).

Sectional classifications of Engler \& Diels (1899), Exell (1978) and Stace (1981) were assessed in view of the phylogenetic studies done by Maurin et al. (2010) and adjusted where necessary. Sections are arranged from ancestral to derived according to the mentioned molecular studies. C. mkuzense is treated as belonging to sect. Spathulipetala. Species are arranged alphabetically within each section. An index is provided at the end for easy access to species. The following species are widespread, well defined and well known or recently described and no voucher specimens are cited for them: C. apiculatum Sond. subsp. apiculatum, C. erythrophyllum (Burch.) Sond., C. hereroense Schinz, C. imberbe, C. kraussii Hochst., C. molle R.Br. ex G.Don, C. vendae A.E.van Wyk and C. zeyheri Sond. Geographical distributions mentioned in the keys refer primarily to the FSA region, namely Botswana, Lesotho, South Africa (RSA: Eastern Cape, Free State, Gauteng, KwaZuluNatal, Limpopo, Mpumalanga, Northern Cape and North-West), Namibia and Swaziland. Species occurring north of the FSA region are indicated by an arrow on the distribution maps. Full range distribution, including all countries and the relevant provinces of South Africa, is given alphabetically under each species.

\section{TAXONOMY}

\section{Subgeneric classification}

Combretum is divided into three subgenera, namely subgen. Combretum, subgen. Cacoucia (Aubl.) Exell \& Stace and subgen. Apetalanthum Exell \& Stace (Stace 1981). The last-named is represented by only one species, $C$. apetalum Wall. ex Kurz which is restricted to

\section{Key to the southern African subgenera of Combretum as modified from Exell (1978)}


Asia. It has leaves with scales and stalked glands, petals are absent and it has 10 stamens in two whorls. The first two subgenera have scales or stalked glands, petals are present, although sometimes reduced and they have eight stamens in one or two whorls. Subgenera are mainly based on the presence or absence of petals, presence or absence of scales on the leaves, presence or absence of stalked glands, the flowers being 4- or 5-merous, colour of the flowers and length of petals.

\section{A. Combretum Loefl. subgen. Combretum}

Scales present, although sometimes inconspicuous or hidden by combretaceous hairs; microscopic stalked glands absent; flowers usually 4-merous; petals usually not red; stamens usually 8 , in 1 or 2 whorls; fruit usually 4 -winged. The structure and arrangement of scales are of great taxonomic significance (Stace 1965). The southern African material is divided into ten sections (Engl. \& Diels 1899; Wickens 1973; Exell 1978; Stace
1980, 1981; Rodman 1990) which fall into two groups. The sectional grouping is based on the size of the scales on the leaves and the resultant two groups are congruent with the two major groups recovered in phylogenetic analyses (Maurin et al. 2010). Each group is represented by five sections. The first five sections treated here belong to the group with small, inconspicuous scales, usually smaller than $100 \mu \mathrm{m}, \pm$ circular in outline or slightly scalloped in sect. Ciliatipetala and divided by few radial and tangential walls. Sometimes the tangential walls are absent as in sect. Angustimarginata, sect. Glabripetala and sometimes in sect. Ciliatipetala. (Figure 1). The last five sections have conspicuous scales, usually larger than $100 \mu \mathrm{m}$, scalloped or irregularly undulate in outline and the scales are divided by many radial and tangential walls (Figure 2). C. imberbe is placed in its own section, sect. Plumbea (Maurin et al. 2010). Note that although $100 \mu \mathrm{m}$ is taken as the cut-off measurement to separate the two groups, intermediates do occur.

\section{Key to sections of subgen. Combretum in FSA region}

1a Scales inconspicuous, usually $<100 \mu \mathrm{m}$ in diam.; scales divided by few radial and tangential walls (tangential walls sometimes absent); stamens 1-seriate (Group 1, p. 137) (Figure 1):

2a Petal apex ciliate or pilose; petals small, $0.5-1.5 \mathrm{~mm}$ long (if apex not ciliate then petals $<1 \mathrm{~mm}$ long as in C. petrophilum); leaf apices often apiculate; fruit $15-30 \mathrm{~mm}$ long $\ldots \ldots \ldots \ldots \ldots \ldots \ldots \ldots \ldots \ldots \ldots \ldots \ldots \ldots \ldots \ldots \ldots \ldots \ldots \ldots \ldots \ldots$. sect. Ciliatipetala $(\mathrm{p} .143)$

$2 \mathrm{~b}$ Petal apex glabrous; petals $1.5-2.5 \mathrm{~mm}$ long; leaf apices not apiculate; fruit $15-50(-100) \mathrm{mm}$ long:

3a Fruit up to $22 \mathrm{~mm}$ long; often with hair-tuft domatia in axil of veins below (except in C. erythrophyllum and C. vendae):

4a Spring leaves at least partly cream-coloured or with some leaves turning bright red in autumn; petals narrowly spathulate; disc margin pilose; style without expanded stigma; fruit sparsely to moderately hairy, not lepidote, mature fruit tinged pink to dark red (rare in $C$. erythrophyllum); stipe $4-8 \mathrm{~mm}$ long $\ldots \ldots \ldots \ldots \ldots \ldots \ldots \ldots \ldots \ldots \ldots \ldots \ldots \ldots \ldots \ldots \ldots \ldots \ldots$ I. sect. Angustimarginata (p.

4b Spring leaves not cream-coloured and autumn leaves not reddish; petals broadly spathulate; disc glabrous with only a very short free margin; style sometimes with expanded stigma; fruit green, glabrous and glutinous, yellowish green, with reddish brown scales, giving it a satiny sheen, wings papery; stipe up to $10 \mathrm{~mm}$ long . . . . . . . . . . . . . . . . .

$3 \mathrm{~b}$ Fruit $35-50(-100) \mathrm{mm}$ and longer; hair-tuft domatia in axil of veins below absent:

5a Leaves large, 100-200 mm long; style without swollen apex; fruit up to $35 \mathrm{~mm}$ long; glutinous when young, glabrous, yellowish green tinged reddish brown; stipe up to $7 \mathrm{~mm}$ long $\ldots \ldots \ldots \ldots \ldots \ldots \ldots \ldots \ldots \ldots \ldots \ldots \ldots \ldots \ldots \ldots \ldots \ldots \ldots$. sect. Glabripetala (p.

5b Leaves medium-sized, 30-100 mm long; style with swollen apex; fruit up to $50(-100) \mathrm{mm}$ long, pale green, glutinous only on body, sparsely hairy or glabrous, drying pale brown, straw-coloured or limegreen; stipe $10-30 \mathrm{~mm}$ long

Ib Scales conspicuous and large, usually $>100 \mu \mathrm{m}$ in diam. $(84-160 \mu \mathrm{m}$ in sect. Breviramea $)$; scales divided by many radial and tangential walls; stamens 1- or 2-seriate (Group 2, p. 147) (Figure 2):

6a Trees; petals subcircular; fruit dark brown or reddish grey to dark purple, glabrous to densely hairy, metallic in appearance, often acute at apex; disc with free pilose margin; cotyledons arising below soil level on a stalk formed by connate petioles ... .

Trees, shrubs, scrambling shrubs or woody climbers; petals linear-elliptic, obovate to spathulate; fruit densely rufous, golden or silvery lepidote, otherwise glabrous; disc without free margin; cotyledons arising above or below soil level:

$7 \mathrm{a}$ Inflorescences usually terminal panicles of spikes or branched spikes; upper hypanthium little developed, flattened; stamens 1-seriate, inserted at margin of disc; fruit usually $<20 \mathrm{~mm}$ long; stipe 1-3 mm long; cotyledons arising above or below soil level; scales contiguous or not:

8a Scrambling shrubs or woody climbers, usually multi-stemmed, not with spine-tipped short branches; disc glabrous or pilose at least on margin; style without stalked scales; fruit not densely silvery lepidote; stipes $<2 \mathrm{~mm}$ long; cotyledons borne above soil

level; scales conspicuous but not contiguous or overlapping ................................. vect. Hypocrateropsis (p.
$8 \mathrm{~b}$ Erect trees up to $15 \mathrm{~m}$, occasionally up to $30 \mathrm{~m}$ tall, single-stemmed, with short lateral branches often spine-tipped; disc margin densely tomentose; style with stalked scales; fruit densely silvery lepidote; stipe 2-3 mm long; cotyledons arising below soil level; scales conspicuous, contiguous and/or overlapping $\ldots \ldots \ldots \ldots \ldots \ldots \ldots \ldots \ldots \ldots \ldots \ldots \ldots \ldots \ldots . \ldots \ldots$. sect. Plumbea $(\mathrm{p}$. orescences usually axillary unbranched spikes; upper hypanthium well developed, campanulate or cup-shaped, not flattened; stamens 2-seriate; fruit 20-35 mm long; stipe up to 11(-15) mm long; cotyledons arising above soil level; scales contiguous or overlapping:

9a Leaves with only 3 or $4(5)$ pairs of primary lateral veins; reticulate venation conspicuous below; hair-tuft domatia absent in axils of veins below; leaf margin flat, usually ciliate; flowers long hairy, not conspicuously lepidote; disc with free pilose margin; fruit densely reddish or golden lepidote $\ldots \ldots \ldots \ldots \ldots \ldots \ldots \ldots \ldots \ldots \ldots \ldots \ldots \ldots \ldots \ldots \ldots \ldots \ldots \ldots \ldots \ldots \ldots \ldots$. sect. Breviramea (p.

$9 \mathrm{~b}$ Leaves with 9-13 pairs of primary lateral veins; only midrib and primary lateral veins conspicuous and prominently raised below; hair-tuft domatia in axial of veins below; leaf margin often undulate, glabrous; flowers not hairy but densely and conspicuously lepidote; disc without free margin; fruit silvery lepidote . 


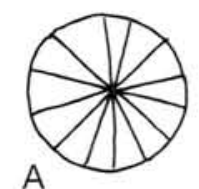

B
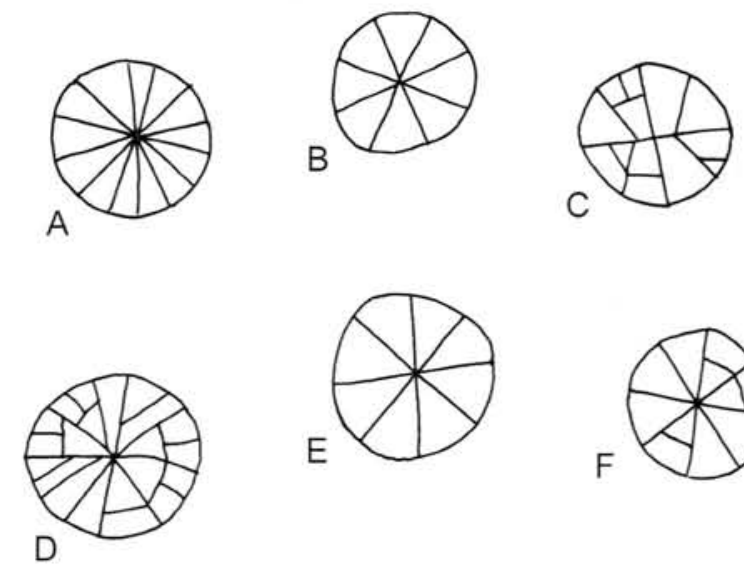

$\mathrm{F}$
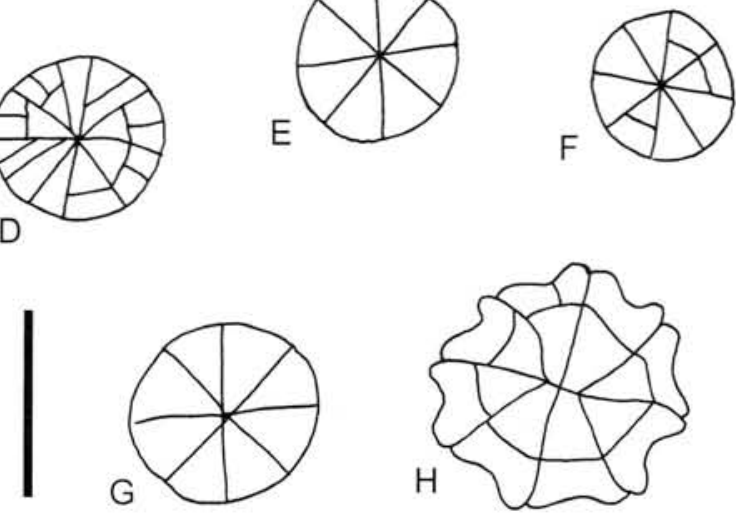

FIGURE 1.-Scales of Combretum subgen. Combretum. Group I. Sections I-V, showing smaller size, \pm circular in outline and divided by few radial and tangential walls, and sometimes tangential walls absent as in sect. Angustimarginata, sect. Glabripetala and sometimes in sect. Ciliatipetala. A. C. erythrophyllum (sect. Angustimarginata); B, C. zeyheri (sect. Spathulipetala); C, C. engleri (sect. Macrostigmatea); D, C. adenogonium (sect. Glabripetala); E, C. apiculatum (sect. Ciliatipetala); F, C. albopunctatum (sect. Ciliatipetala); G, C. molle (sect. Ciliatipetala); H, C. molle. Taken from Stace (1969) and Exell (1978). Scale bar: $80 \mu \mathrm{m}$. Artist: Daleen Roodt.

South Africa and Swaziland. It is characterized by their 4-merous flowers; upper hypanthium cupuliform to campanulate; petals subcircular, obovate, spathulate or narrowly elliptic, glabrous, margins not ciliate; stamens 8,1 -seriate, inserted shortly above margin of disc; disc glabrous with a pilose margin very shortly free for up to $0.5 \mathrm{~mm}$; style not expanded; fruit 4-winged; scales inconspicuous, often obscured by hairs and/or glutinous secretions, $\pm 50-75$ $\mu \mathrm{m}$ in diam., weakly scalloped, delimited by $8-16$ primary radial walls alone; cell walls very thin (Exell 1970, 1978).
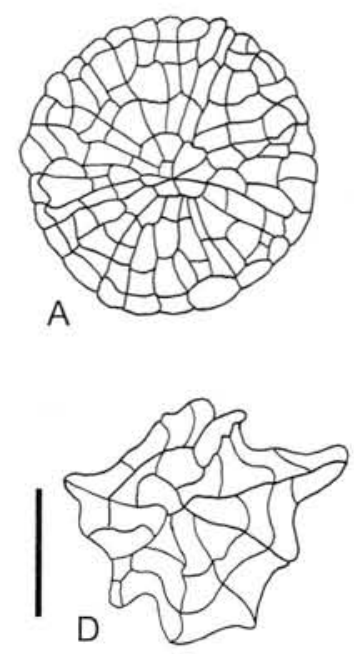
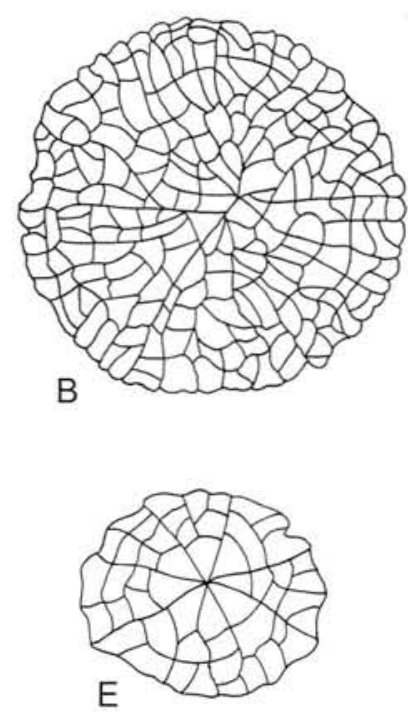

Other diagnostic characters based on field observations are: the bark is \pm smooth or flaking in small, rather papery pieces in older specimens; the first spring leaves are often partly or completely cream-coloured or at least some leaves turning red in autumn; the flowers have calyx lobes tinged reddish purple; the mature fruits are usually partly or completely tinged pink to dark red (Van Wyk 1984). The secondary xylem of older stems has islands of interxylary phloem (Verhoeven \& Van der Schijff 1973).

Engler \& Diels (1899) and Exell (1978) included C. woodii Dümmer under C. kraussii Hochst. Rodman (1990) considers $C$. woodii to be conspecific with $C$. erythrophyllum. Burtt Davy (1926), Van Wyk (1984), Carr (1988) and Jordaan $(2003,2006)$ consider C. woodii to be a distinct species. There are ample DNA and morphological differences to separate $C$. woodii from $C$. kraussii and C. erythrophyllum (Maurin et al. 2010). See Carr (1988) for differences between these three species. Exell $(1970,1978)$ included $C$. nelsonii and $C$. woodii in the synonymy of $C$. kraussii. Chemosystematic studies conducted by Carr \& Rogers (1987) support the recognition of $C$. nelsonii Dümmer, C. kraussii and C. woodii as three distinct species. C. caffrum (Eckl. \& Zeyh.) Kuntze and $C$. vendae also belong to this section. A form of Combretum vendae with glabrous leaves occurs in the western Soutpansberg and represents a new subspecies to be described elsewhere.

\section{Key to species of Combretum sect. Angustimarginata based on Van Wyk (1984)}

la Leaves glabrous below when mature, often with hair-tuft domatia:

2a Flowers in laxly elongated spikes (25-)35-60(-85) mm long:

3a Leaf lamina with secondary lateral veins raised but intersecondary veins \pm plane below; scales with $8-10$ radial cells; trees; forest; widespread ............ 3. C. kraussii

3b Leaf lamina with both secondary and intersecondary veins conspicuously raised below; scales with 10-16 radial cells; trees, shrubs or climbers; forest and savanna; Limpopo Province, Mpumalanga, KwaZuluNatal and Swaziland .................. 6. C. woodii

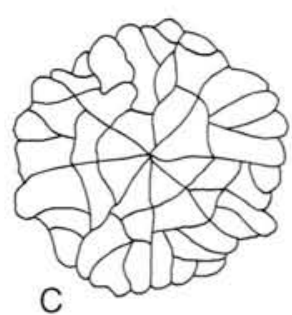

FIGURE 2.-Scales of Combretum subgen. Combretum. Group 2. Sections VI-X, showing larger size, \pm scalloped in outline and divided by many radial and tangential walls. A, C. patelliforme (sect. Hypocrateropsis); B, C. celastroides (sect. Hypocrateropsis); C, C. collinum (sect. Merallicum); D, C. hereroense (sect. Breviramea); E, C. elaeag. noides (sect. Campestria); F, C. imberbe (sect. Plumbea). Scale bar: $80 \mu \mathrm{m}$. Artist: Daleen Roodt. 


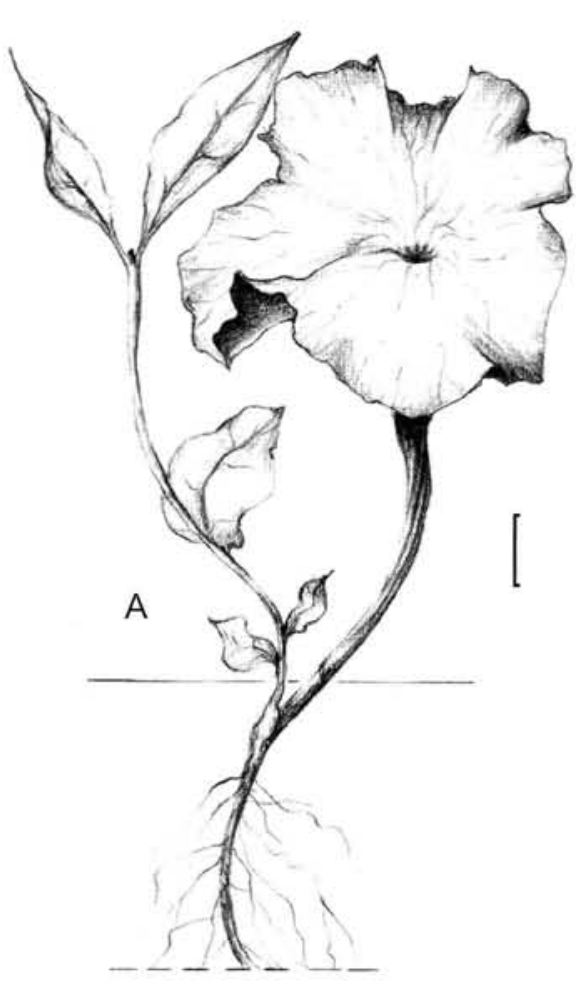

2b Flowers in congested subcapitate spikes (10-)15-20(-35) $\mathrm{mm}$ long:

4a Usually shrubs; leaves elliptic, obovate-elliptic or obovate; flowers with upper hypanthium divided into a lower \pm campanulate part containing the disc, and an expanded \pm cupuliform upper part; Limpopo Province and Mpumalanga ................... 4. . nelsonii

4b Usually trees; leaves narrowly elliptic or lanceolate; flowers with upper hypanthium \pm cupuliform, not divided into a lower and upper part; Eastern Cape ....

............................... 1. C. caffrum

1b Leaves distinctly hairy below when mature, at least on midrib and lateral veins:

5a Reticulate venation of leaf lamina conspicuously raised below; Venda (Limpopo Province) .......... 5. C. vendae

5 b Reticulate venation of leaf lamina plane or slightly raised below; widespread along watercourses ..............

2. C. erythrophyllum

1. Combretum caffrum (Eckl. \& Zeyh.) Kuntze, Revisio generum plantarum 3,2: 87 (1898); J.D.Carr: 40 (1988); M.Coates Palgrave: 797 (2002). Type: South Africa, Eastern Cape, 'ad ripas fluminum Kat et Vischrivier (Albany), Zondagsrivier (Uitenhage), Keyskamma et Keyrivier (Caffraria)', Ecklon \& Zeyher 421 [SAM0036373-2, lecto. e!, designated here; FR e!, HBG e!, $\mathrm{K}$ e!, $\mathrm{M}$ e!, W e!, isolecto.].

\section{Dodonaea caffra Eckl. \& Zeyh.: 55 (1834-1835).}

D. conglomerata Eckl. \& Zeyh.: 55 (1834-1835). Type: South Africa, Eastern Cape, 'Inter frutices fluvii Katrivier prope Fort Beaufort Caffraria terminis', Ecklon \& Zeyher 422 [SAM0036375-2 e!, lecto., designated here; $\mathrm{K}$ e!, $\mathrm{M}$ e!, isolecto.].

C. salicifolium E.Mey. ex Hook.: t. 592 (1843); Sond.: 511 (1862); Dümmer: 182 (1913). Type: South Africa, Eastern Cape, 'Sundays River', Burke 592 (K, holo. e!; BM, iso. e!).
FIGURE 3.--Seedling morphology of Combretum zeyheri (A) and $C$. mkuzense (B). Solid transverse lines depict ground level. In C. zeyheri cotyledons fused to form a subcircular peltate structure which terminates primary stem. Growth in length is resumed by a lateral bud from a point below fused cotyledons (sympodial growth). In C. mkuzense growth in length of stem commences from what seems to be the primary growing tip located between two opposite cotyledons (monopodial growth). Scale bar: $10 \mathrm{~mm}$ Artist: Daleen Roodt.
C. dregeamum C.Presl: 73 (1844). Type: South Africa, Eastern Cape, Klein Winterhoek between Zoutpansnek and Enon, Drège $6849 a$ (?PR, holo.; BM e!, HBG e!, K e!, MO e!, SAM e!, W e!, iso.).

Note: Ecklon \& Zeyher 421, 422, both at SAM, are chosen as lectotypes for Combretum caffrum (=Dodonaea caffra), and D. conglomerata respectively, because they have the protologues and annotations attached to the specimens.

\section{Distribution: RSA: Eastern Cape (Figure 4).}

2. Combretum erythrophyllum (Burch.) Sond. in Linnaea 23: 43 (1850); Sond.: 509 (1862); Engl. \& Diels: 26 (1899); Dümmer: 140 (1913); Bews: 146 (1921); Exell \& Roessler: 8 (1966); Exell: 7 (1968); Exell: 112 (1978); J.D.Carr: 69 (1988); Pooley: 356 (1993); A.E.van Wyk \& P.van Wyk: 330 (1997); McCleland: 460 (2002); M.Coates Palgrave: 802 (2002). Type: South Africa, Northern Cape, 'on the banks of the Kygariep' (Griqualand West, Kalahari region, Herbert Div., right bank of the Vaal River at Blaauwbosch Drift), Burchell 1749 (K, holo. e!; PRE, iso.!).

\section{Terminalia erythrophylla Burch.: 400 (1822).}

C. glomeruliflorum Sond.: 47 (1850); Sond.: 509 (1862); Engl. \& Diels: 26 (1899); Burtt Davy: 247 (1926); Codd: 130 (1951). Type: South Africa, Natal [KwaZulu-Natal], Port Natal [Durban], Gueinzius 62 (?S, holo.; HBG e!, K e!, P e!, W e!, iso.).

C. riparium Sond.: 47 (1850); Sond.: 511 (1862). C. glomeruliflorum Sond. var. riparium (Sond.) Burtt Davy: 247 (1926); O.B.Mill.: 42 (1948). Type: South Africa, [?Gauteng], 'On Magalisriver', Zeyher 549 ( $\mathrm{S}$, holo. e!; $\mathrm{BM}, \mathrm{K}$ e!, SAM, iso.).

C. sonderi Gerrard ex Sond.: 511 (1862). Type: South Africa, Natal [KwaZulu-Natal], 'On the Nototi River, near Port Natal', Gerrard 138 (?TCD, holo.). 


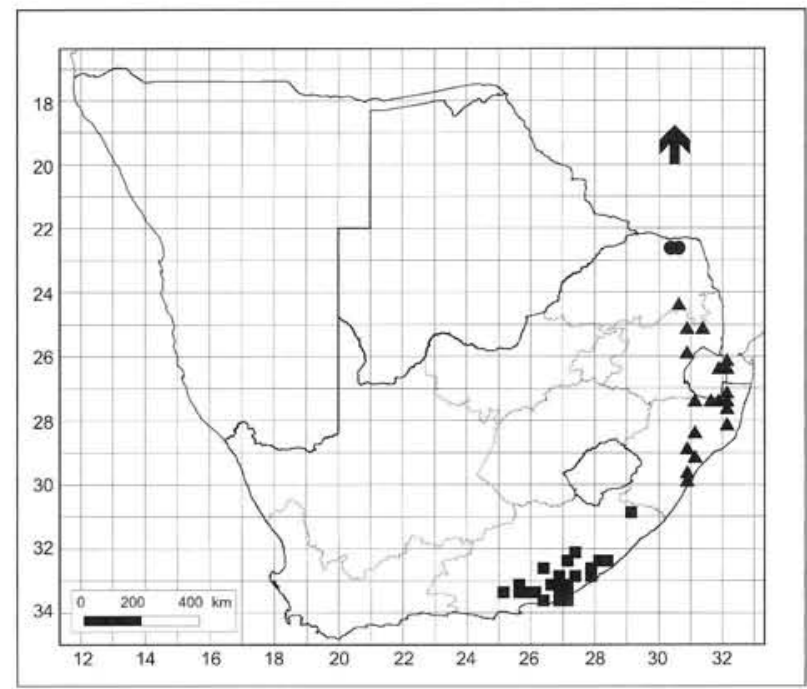

FIGURE 4.-Known distribution in FSA region of Combretum vendae, - C. woodii, $\mathbf{\Delta}$; and C. caffrum,

C. erythrophyllum (Burch.) Sond. var. obscurum Van Heurck \& Müll.Arg.: 237 (1871); Dümmer: 147 (1913). C. glomeruliflorum Sond. var. obscurum (Van Heurck \& Müll.Arg.) Burtt Davy: 37, 247 (1926). Type: South Africa, 'Africa australis, woods on Crocodile River', Zeyher 550 (K, holo. e!; P, iso. e!).

C. lydenburgianum Engl. \& Diels: 26 (1899); Eyles: 428 (1916). Type: South Africa, [Mpumalanga], near waterfall in town of Lydenburg, Wilms 212 (B, holo.†; K, lecto. e!, designated here; BM, E e!, isolecto.).

Note: Wilms 212, the holotype of Combretum lydenburgianum, was destroyed in Berlin during World War II and the Kew specimen is chosen as lectotype, which is the best specimen of the isotypes that are available.

Distribution: Botswana, Mozambique; RSA: Eastern Cape, Gauteng, KwaZulu-Natal, Limpopo Province, Mpumalanga, Northern Cape, North-West; Swaziland, Zambia, Zimbabwe (Figure 5).

3. Combretum kraussii Hochst. in Flora 27: 424 (1844); Sond.: 510 (1862); Dümmer: 164 (1913); Bews:

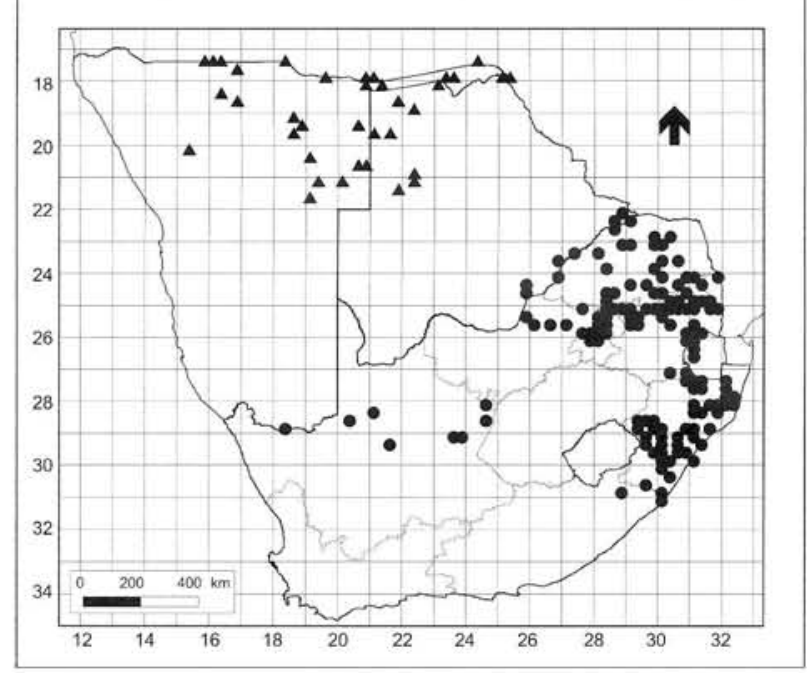

FIGURE 5.-Known distribution in FSA region of Combretum erythrophyllum, ; and $C$. engleri, $\mathbf{A}$
147 (1921); Burtt Davy: 246 (1926); Exell: 7 (1968); Exell: 114 (1978); J.D.Carr: 89 (1988); Pooley: 358 (1993); A.E.van Wyk \& P.van Wyk: 332 (1997); McCleland: 462 (2002); M.Coates Palgrave: 804 (2002). Type: South Africa, Natal [KwaZulu-Natal], Port Natal [Durban], 'in sylvis primitivis circa Umlaas River', Oct. 1839, Krauss 253 [B, holo.†; K00022665, lecto. e!, designated here; BM e!, M e!, MO e!, OXF, TCD e!, W e!, $\mathrm{Z}$ e!, isolecto.].

C. lucidum E.Mey. ex Drège: 174 (1843); Dümmer: 164 (1913). Type: South Africa, [KwaZulu-Natal], between Umkomanzi and Umzimkulu Rivers, Drège s.n. (HBG, holo. e!; K, iso. e!).

Note: the holotype of Combretum kraussii at Berlin was destroyed in World War II and from all the extant isotypes, the fruiting specimen at Kew was chosen, because it shows the leaf characters the best, namely totally glabrous, obovate with a rounded to emarginate apex, with very conspicuous reticulate venation below, margin flat, not wavy and longitudinally folded upwards along the midrib as in $C$. woodii, and the apices not acute to acuminate as in C. erythrophyllum, its two closest allies; most of the other isotypes are just fragments, except the BM specimen which is flowering.

Distribution: Mozambique; RSA: Eastern Cape, KwaZulu-Natal, Limpopo Province, Mpumalanga; Swaziland (Figure 6).

4. Combretum nelsonii Dümmer in The Gardeners' Chronicle, ser. 3: 164 (1913); Burtt Davy: 246 (1926); A.E.van Wyk: 132 (1984); A.E.van Wyk \& P.van Wyk: 334 (1997); McCleland: 466 (2002); M.Coates Palgrave: 807 (2002). Type: South Africa, [Limpopo Province], mountain gorge, near Groot Vley, Pienaars River, Nelson 91 (K, holo. e!; PRE, iso.!).

Distribution: RSA: Limpopo Province, Mpumalanga (Figure 6).

5. Combretum vendae A.E.van Wyk in South African Journal of Botany 3: 125 (1984); J.D.Carr: 140 (1988); M.Coates Palgrave: 811 (2002). Type: South Africa, [Limpopo Province], Vuvha NE of Thengwe,

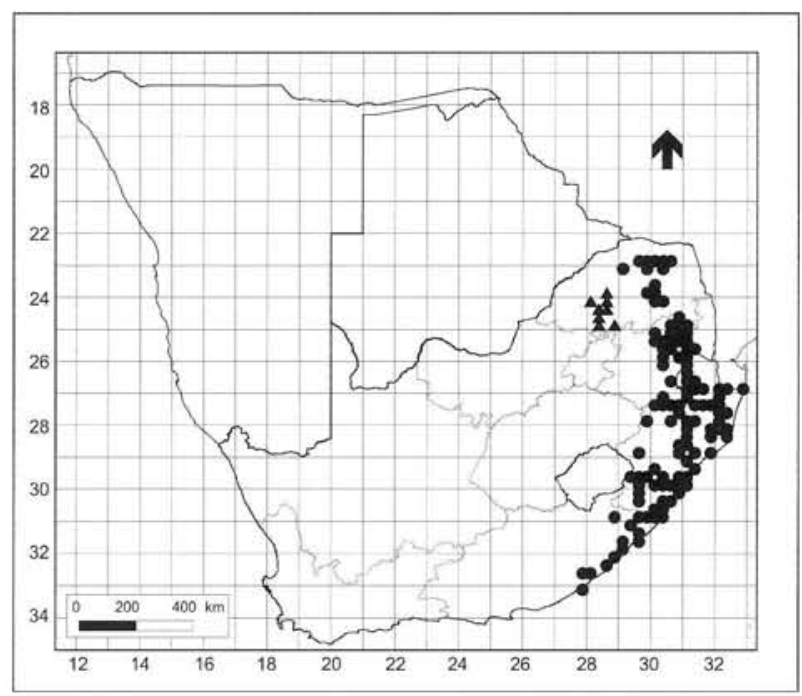

FIGURE 6.-Known distribution in FSA region of Combretum kraussii, ; and C. nelsonii, 
near Muledzhi Village, Van Wyk 3913 (PRU, holo.!; K e!, P e!, PRE!, iso.).

\section{Distribution: RSA: Limpopo Province (Figure 4).}

6. Combretum woodii Dümmer in The Gardeners' Chronicle, ser. 3: 181 (1913); Burtt Davy: 245 (1926); Compton: 395 (1976); J.D.Carr: 147 (1988); Pooley: 358 (1993); McCleland: 468 (2002); M.Coates Palgrave: 812 (2002). Type: South Africa, [Mpumalanga], Barberton Dist., Kaap River Valley, Galpin 1176 (K, lecto. e!, designated here; NH e!, PRE!, SAM e!, isolecto.).

Note: Dümmer (1913) mentioned two specimens in his protologue, Wood 522 and Galpin 1176. The latter syntype in Kew where Dümmer worked for a few years is chosen, because it comprises flowers and fruit, and duplicates are housed in many other herbaria. This specimen (lectotype here chosen) shows the distinguishing characters which separate Combretum woodii from C. kraussii: leaves membranous, widest in the middle, folded along the midrib, and narrower elliptic fruit which are totally glabrous. The syntype Wood 522 in BM was not examined and is not available on the Aluka website, but a duplicate exists in the Zürich Herbarium, which does not show the leaves folding along the midrib as clearly as the Galpin specimens.

Distribution: probably Mozambique; RSA: KwaZuluNatal, Limpopo Province, Mpumalanga; Swaziland (Figure 4).

\section{Diels (1899)}

II. Combretum sect. Spathulipetala Engl. \&

This section is characterized by leaves with hairy petioles, usually hair-tuft domatia in axils of veins below; 4-merous flowers; petals obovate-spathulate to spathulate, glabrous; stamens 8, 1-seriate, inserted at margin of disc; disc with pilose margin free for up to $2 \mathrm{~mm}$; style with swollen apex; fruit 4-winged, large in genus, usually up to $50 \times 50 \mathrm{~mm}$ and occasionally up to $100 \times 80$ $\mathrm{mm}$, with rigid wings; stipe up to $20-25 \mathrm{~mm}$ long; scales $\pm 40-85 \mu \mathrm{m}$ in diam., circular but slightly convexly scalloped; cells delimited by $7-9$ radial walls and additional few tangential and extra radial walls; marginal cells 7-12 (Exell 1978).

Members of this section show two distinct types of germination (Figure 3 ) suggesting that the group is probably not a natural one. Four main types of germination are known in Combretum, the taxonomic significance of which is not clear (Exell \& Stace 1972). C. zeyheri is unusual in also having the cotyledon blades fused into a subcircular peltate structure. According to Exell \& Stace (1972) the fruit are adapted for blowing along by wind at ground level.

Although provisional molecular data have indicated that a re-evaluation of the taxonomic concepts of sections Spathulipetala and Macrostigmatea are needed (Maurin et al. 2010), formal taxonomic adjustment must await further phylogenetic analyses based on more taxa and more gene sequences. This should also take into account the data derived from all other fields, including micro- and macromorphology, vegetative and reproductive characters, phytogeography and chemis- try. Only a combination of such evidence will provide a clear picture of the true phylogeny and evolution of the group. Traditionally Combretum zeyheri has been the only member of this section. Tentatively Combretum mkuzense is placed in this section. Hennessy \& Rodman (1995) reduced $C$. mkuzense to synonymy under C. zeyheri. The latter is a single-stemmed tree, whereas C. mkuzense is a scrambling shrub. C. mkuzense and C. zeyheri also have markedly different seedlings (Figure 3 ). There is abundant morphological and molecular (Maurin et al. 2010) evidence that C. mkuzense, C. zeyheri and a third undescribed species from the northern Kruger National Park (as C. mkuzense in McCleland 2002: 464) with much smaller fruit, are separate entities.

\section{Key to species}

la Usually single-stemmed tree with branches not trailing; leaf lamina $(45-) 70-120(-200) \times 30-50(-110) \mathrm{mm}$; lateral veins in $(5-) 7-12$ pairs ............... 8. C. zeyheri

Ib Usually multi-stemmed shrub or tree with branches with tendency to trail; leaf lamina $(25-) 45(-80) \times(10-) 20(-30)$ $\mathrm{mm}$; lateral veins in up to 5 pairs:

2a Fruit 50-70 mm long; KwaZulu-Natal ....... . 7. C. mkuzense 2b Fruit smaller, 38-55 × 35-60 mm; Limpopo Province .

Combretum sp. nov.

7. Combretum mkuzense J.D.Carr \& Retief in Bothalia 19: 38 (1989); Pooley: 360 (1993); McCleland: 458 (2002); M.Coates Palgrave: 805 (2002). Type: South Africa, [KwaZulu-Natal], Mkuze Game Reserve headquarters, Carr 187 (PRE, holo.!; K, iso. e!).

\section{Distribution: RSA: KwaZulu-Natal (Figure 7).}

8. Combretum zeyheri Sond. in Linnaea 23: 46 (1850); Sond.: 511 (1862); Engl. \& Diels: 59 (1899); Dümmer: 116 (1913); Burtt Davy: 248 (1926); O.B.Mill.: 44 (1948); Codd: t. 1230 (1956); Exell \& Roessler: 11 (1966); Exell: 8 (1968); Liben: 72 (1968); Exell \& J.G.Garcia: 66 (1970); Wickens: 31 (1973); Exell: 122 (1978); Vollesen: 54 (1980); J.D.Carr: 151 (1988); Pooley: 360 (1993); A.E.van Wyk \& P.van Wyk: 338 (1997); McCleland: 470 (2002); M.Coates Palgrave: 812 (2002); Curtis \& Mannheimer: 488 (2005). Type: South Africa, 'Africa australis, in

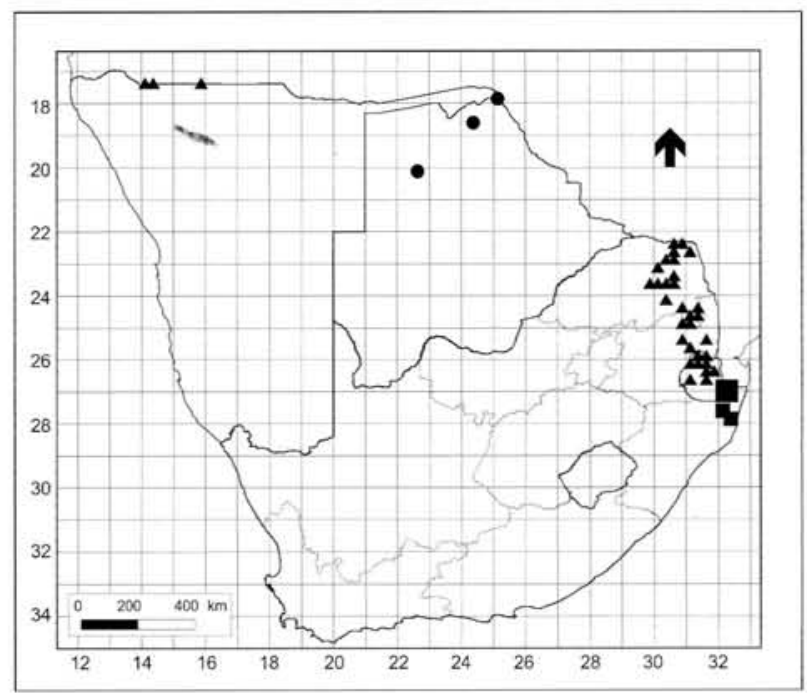

FIGURE 7.-Known distribution in FSA region of Combretum adenogonium, ; $C$. collinum subsp. suluense (provisional; requires confirmation), $\mathbf{\Delta}$; and $C$. mkuzense, 
silvis montis Magalisberg', Zeyher 552 (S, holo. e!; BM, K e!, MEL, P e!, SAM e!, TCD, W e!, Z e!, iso.).

C. tinctorum Welw. ex M.A.Lawson: 430 (1871); Engl. \& Diels: 30 (1899). Type: Angola, Cuanza Norte, Cacuso, Pedras de Guinga, Welwitsch 4373 (LISU, holo. e!; BM e!, COI, $\mathrm{K}$ e!, $\mathrm{P}$ e!, iso.).

C. oblongum F.Hoffm.: 34 (1889). Type: [Tanzania], Tabora Dist., Kakoma, Boehm $87 a$ (B, holo $\ddagger$ K, fragment e!).

C. antunesii Engl. \& Diels: 58 (1899). Type: Angola, Lubango, Huila, Antumes 17 (COI, holo.).

C. odontopetalum Engl. \& Diels: 60 (1899); De Wild.: 139 (1921). Type: [Namibia], 'Amboland, Omupanda, Unkuanyama', Wulfhorst 14 (Z, lecto. e!, designated here; $\mathrm{K}$, isolecto. e!).

C. lopolense Engl. \& Diels: 502 (1907); De Wild.: 138 (1921). Type: Angola, Benguella.-Lopol., Dekindt 48 (B, holo.广; BM e!, K e!, iso.).

C. calocarpum Gilg ex Dinter: 169 (1919); Suess.: 336 (1953). Type: [Namibia], 'Hereroland', Neitsas, Dinter 795 (SAM, lecto. e!, designated here; $\mathrm{BM}, \mathrm{E} \mathrm{e}$ !, isolecto.).

Note: both syntypes of Combretum odontopetalum, Schinz 1050 and Wulfhorst 14, are housed in the Zürich Herbarium, but only the Wulfhorst specimen has a duplicate in another herbarium, namely in Kew, and is therefore chosen as the lectotype.

Dinter (1919) mentioned syntypes in his protologue of Combretum calocarpum: Dinter s.n., Dinter 795 and Dinter 2877 . The large fruit, the most distinctive character of this species in Namibia, is best seen in the Dinter 795 specimen in SAM; it is here chosen as the lectotype.

Distribution: Angola, Botswana, Democratic Republic of the Congo (DRC), Kenya, Malawi, Mozambique, Namibia; RSA: Gauteng, KwaZulu-Natal, Limpopo Province, Mpumalanga, North-West; Swaziland, Tanzania, Zambia, Zimbabwe (Figure 8).

III. Combretum sect. Macrostigmatea Engl. \& Diels: 24 (1899); Stace: 158 (1969); Exell: 176 (1970); Wickens: 21 (1973); Exell: 115 (1978); Stace: 336 (1981).

Species in this section have yellow, 4-merous, glutinous flowers arranged in subcapitate spikes. The nectariferous disc is glabrous with only a very short free margin in Combretum schumannii Engl. and C. engleri Schinz. C. kirkii M.A.Lawson (Malawi, Mozambique, Zambia, Zimbabwe) and C. gillettianum Liben (DRC, Tanzania, Zambia) also belong to this section. Whether sections Macrostigmatea and Spathulipetala should be united, as suggested by provisional molecular analyses, must await further study (see under sect. Spathulipetala above).

Dinter (1919) published the name Combretum parvifolium, but the epithet was antedated by $C$. parvifolium Engl. (1895). Schinz's 'engleri' is, however, the earliest. Exell (1970) keeps C. engleri and C. schumannii as two separate species, but Wickens (1973) and Exell (1978) consider $C$. engleri to be conspecific with $C$. schumannii on the basis that the flowers of both entities have a glabrous nectariferous disc with a short free margin and the fruit are glabrous except for peltate scales. However, Carr (1988) maintains these two entities as separate species as they differ in habit and geographical distribution.

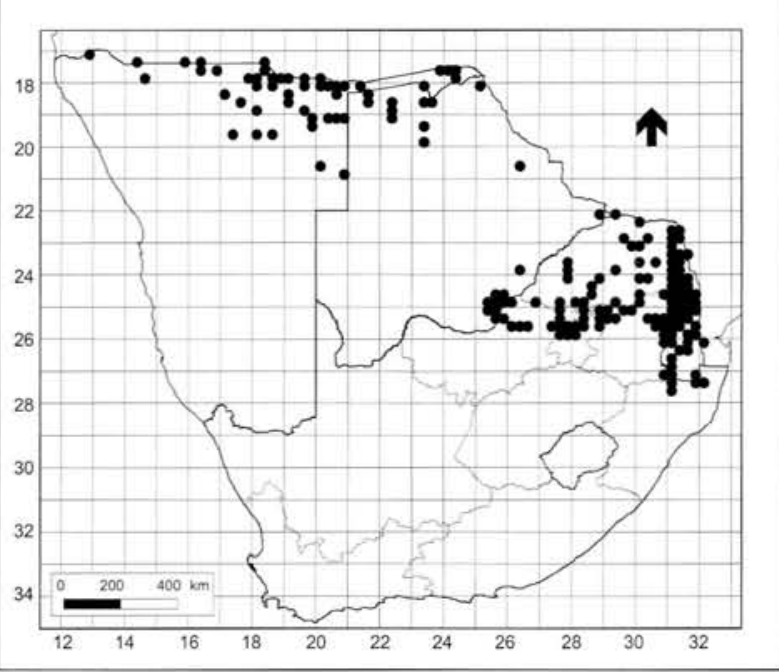

FIGURE 8.-Known distribution in FSA region of Combretum zeyheri.

He also points out that $C$. schumannii has been successfully propagated from seed in cultivation, whereas all attempts to germinate seed of $C$. engleri have failed. Based on flower and scale morphology, Hennessy \& Rodman (1995) also concluded that $C$. engleri and $C$. schumannii are separate species. Engler (1895) based C. schumannii on a Holst specimen collected in Lushoto District, Tanzania. C. engleri is a multi-stemmed shrub up to $4 \mathrm{~m}$ tall, growing in mixed woodland and savanna, often semi-arid and on Kalahari sands in Angola, Zambia, Namibia, Botswana and western Zimbabwe (Wankie District). After viewing the type on the Aluka Digital Library, it is clear that $C$. schumannii does not occur in the FSA region and it is therefore a misapplied name in this region. Specimens from Namibia and Botswana previously named $C$. schumannii are all $C$. engleri. Carr (1988) mentions that C. schumannii is a tree up to $18 \mathrm{~m}$ tall with flaky bark, occurring in coastal and inland forest in Kenya, Tanzania, Malawi and northern Mozambique. There are enough morphological distinctions between these two species to keep them separate (Carr 1988; Hennessy \& Rodman 1995).

9. Combretum engleri Schinz in Bulletin de 1'Herbier Boissier sér. 2,1: 878 (1901); Stace: 14 (1961); Exell \& Roessler: 8 (1966); Exell: 7 (1968); Exell: 176 (1970): Exell \& J.G.Garcia: 55 (1970); J.D.Carr: 66 (1988); M.Coates Pal grave: 801 (2002); Curtis \& Mannheimer: 476 (2005). Type: [Namibia], Ombalambuenge, Apr. 1896, Rautanen 236 (Z, holo. e!).

\section{C. parvifolium Dinter: 170 (1919), nom. illegit.}

C. myrtillifolium Engl: 695 (1921). Type: [Namibia], Naruchas, Dünen, Dinter 7278 (PRE, lecto.!, designated here; BOL, $\mathrm{K}$ e!, isolecto.) \& [Namibia], Neitsas, Dinter 668 (BM, fragment, e!, SAM, paralecto. e!).

C. chlorocarpum Exell: 167 (1928). Type: Angola, Oct. 1906, Gossweiler 324 I (BM, holo. e!; COI, LISJC, iso.).

Note: Dinter (1919) mentioned two specimens in his protologue of Combretum parvifolium, Dinter 668 and 7278 , collected in Namibia. This name is a later homonym and therefore illegitimate and Engler (1921) chose the new name C. myrtillifolium. The PRE specimen of Dinter 
7278 , which must be an isosyntype, is chosen as lectotype for $C$. myrtillifolium because it has flowers and fruit.

Distribution: Angola, Botswana, DRC, Namibia, Zambia (Figure 5).

\section{(1899)}

IV. Combretum sect. Glabripetala Engl. \& Diels

While working on the Flora of Ethiopia, Vollesen (1986) realized that Combretum adenogonium is an earlier name for C. fragrans F.Hoffm. Wickens (1973) considers $C$. adenogonium ( $=C$. fragrans) as occurring from Ethiopia in the north through Uganda, Kenya, Tanzania, Malawi, Zimbabwe, Mozambique, Zambia, Malawi, southwards to Zimbabwe and Botswana and westwards to Burkina Faso, Benin, Nigeria and the Congo. It is characterized by relatively large leaves, up to $180 \times 90 \mathrm{~mm}$, and glutinous leaves and fruit. The presence of this taxon in the FSA region is indicated by two old specimens in PRE, both dated pre-1950 and collected in Botswana. It needs to be re-collected to confirm the existence of this species in the FSA region.

10. Combretum adenogonium Steud. ex A.Rich., Tentamen florae abyssinicae 1: 266 (1848); F.W.Andrews: 204 (1950); Vollesen: 962 (1986); Wickens: 29 (1973); Vollesen: 117 (1995); A.E.van Wyk \& P.van Wyk: 326 (1997); M.Coates Palgrave: 795 (2002). Type: Ethiopia, Sabra, May 1840, Schimper 1289 (P, holo. e!; $\mathrm{BR}$ e!, $\mathrm{K}$ e!, $\mathrm{MO}$ e!, W e!, Z e!, iso.).

C. fragrans F.Hoffm.: 31 (1889); Engl.: 289 (1895); Wickens: 29 (1973); Exell: 183 (1970); Exell: 120 (1978); Liben: 18 (1983). Type: [Tanzania], Pa-Kabombue, Oct. 1881, Böhm 16 a (B, syn.†; Z, lecto. e!, designated here; $\mathrm{K}$, isolecto. $\mathrm{e}$ !).

C. ghasalense Engl. \& Diels: 47 (1899); F.W.Andrews: 206 (1950); Exell: 8 (1968); Liben: 75 (1968). Type: Sudan, Bahr el Ghazal, Sabbi [Ssabi], 1869, Schweinfurth 2730 (B, syn.†; P, lecto. e!, designated here; $\mathrm{K}$, isolecto. e!).

C. multispicatum Engl. \& Diels: 47 (1899). Type: Sudan, 'Im Lande der Bongo', Sabbi, Nov. 1864, Schweinfurth 2662 (B, syn.†; P, lecto. e!, designated here; $\mathrm{K}$ e!, PRE!, Wty e!, isolecto.).

C. undulatum Engl. \& Diels: 48 (1899). Type: Sudan, Ngama, im Lande der Mittu, 1869, Schweinfurth 2815 (B, syn.†; P, lecto. e!, designated here; $\mathrm{K}$ e!, PRE!; WU e!, isolecto.).

C. ternifolium Engl. \& Diels: 49 (1899); O.B.Mill.: 43 (1948). Type: [Tanzania], Morogoro Dist., Mgeta, Stuhlmann 9272 (B, holo. $\dagger$; $\mathrm{K}$, fragment, lecto. e!, designated here; ?BM, isolecto.).

Notes: Hoffmann (1889) mentioned two syntypes in his protologue of Combretum fragrans: $B \ddot{h m} 16 \mathrm{a}$ and Böhm 32a. Both were destroyed in World War II, but fortunately duplicates survived in Zürich $(Z)$ and Kew (K). Böhm $16 a$ in Z, which shows the large ternate leaves the best, is chosen as the lectotype. Duplicates of the syntype, Böhm 16a, are not available on the Aluka Library, whereas only a fragment of the other syntype, Böhm 32a, survived in Kew.

Engler \& Diels (1899) described Combretum ghasalense, C. multispicatum and C. undulatum: all these three names are based on types collected in the Sudan, and C. ternifolium is based on a specimen collected in Tanzania. The holo- and syntypes, all at Berlin, were destroyed and lectotypes are selected from material in Paris (P) and Kew (K).
Distribution: Benin, Botswana, Burkina Faso, Central African Republic, Cameroon, Cote d'Ivoire, DRC, Ethiopia, Ghana, Guinea-Bissau, Kenya, Malawi, Mozambique, Nigeria, Sudan, Tanzania, Togo, Uganda, Zambia, Zimbabwe (Figure 7). (1899)

V. Combretum sect. Ciliatipetala Engl. \& Diels

This section comprises about 60 species and is the largest in the genus. Although the species are morphologically diverse they do seem to form a natural group. All members of this section have small petals which are ciliate or pilose at the apex, except in Combretum petrophilum, and the disc has a short, free, pilose margin. The scales are relatively small, $40-130 \mu \mathrm{m}$ in diam., \pm circular, scalloped at the margin with radial and tangential walls. Stace (1969) separates this section into two large aggregates centred on $C$. apiculatum and $C$. molle, but these two groups are not supported as natural entities by molecular evidence (Maurin et al. 2010). Leaves in the section vary from very glabrous, glutinous and always with apiculate apices in $C$. apiculatum subsp. apiculatum and $C$. petrophilum, with hairs only on the margin and main vein and with acute to rounded apices in $C$. edwardsii Exell, to very hairy leaves in $C$. albopunctatum Suess., C. apiculatum subsp. leutweinii (Schinz) Exell (apiculate apices), C. moggii Exell, $C$. molle and C. psidioides. Apices of leaves in C. molle are usually round, emarginate to abruptly acuminate with a long acumen or mucron, but are occasionally apiculate.

Combretum apiculatum subsp. apiculatum is widespread in Angola, Namibia, Botswana, the northern parts of South Africa, Zimbabwe, Zambia, Malawi and Mozambique and grows in savanna woodland, often on Kalahari sands, whereas subsp. leutweinii has a more restricted range in Namibia and Botswana, mainly in karstveld and mopaneveld. C. apiculatum subsp. boreale Exell is reinstated for the narrow-leaved form of C. apiculatum mainly from Tanzania and Kenya. Wood (1908) mentions C. glutinosum Guill. \& Perr. ex DC. as occurring in KwaZulu-Natal, but it is a West African species that does not occur in southern Africa.

Combretum moggii and C. molle are both very hairy, especially their leaves and young stems. C. moggii is usually a multi-stemmed, small shrub up to $3(-5) \mathrm{m}$ tall growing in sandy soil in the crevices between outcropping quartzitic rocks (Carr 1988). It has a smoother bark, smaller and narrower leaves with more silky hairs and longer inflorescences than C. molle. The latter is usually a single-stemmed tree up to $9 \mathrm{~m}$ tall, with main branching commencing 1.5-3.0 m above ground level (Carr 1988). Besides the former Transvaal records of C. moggii (Exell 1968; Carr 1988; Hennessy 1991a) additional localities were recorded in Swaziland (Loffler \& Loffler 2005) and northern KwaZulu-Natal (Figure 12).

Combretum molle has a very wide distribution, from Saudi Arabia, Yemen and Ethiopia, from where the type is, in the north to KwaZulu-Natal (=C. gueinzii Sond.) in the south and westwards to West Africa, DRC and Angola, but it is absent from Namibia and most parts of Botswana. Exell (1978) points out that there is a great deal of variation in leaf shape, size and indumentum, 
and that the species grows in various ecological habitats. A polymorphic species, $C$. molle is one of the aggregate groups of Combretum in Africa that needs to be investigated further for the possibility of recognizing distinct subspecies. Wickens (1973) for instance, recognized three forms of $C$. molle in East Africa.

Combretum petrophilum, as currently defined, comprises populations from the Strydom Tunnel in the Abel Erasmus Pass, Mariepskop, Loskop Dam, Doornkop and Mogol Nature Reserve. Leaves have an undulate margin, the base is often asymmetric and subcordate; the often twisted apex tapers to a long, narrow acumen with a mucro and is therefore described as apiculate.

Engler \& Diels (1899) placed Combretum psidioides in sect. Glabripetalae, but Exell \& Garcia (1970) and Stace (1981) later transferred it to sect. Ciliatipetala. Maurin et al. (2010) support the latter placement. In the $F S A$ region, $C$. psidioides is represented by two subspecies: the typical one which occurs in northern Botswana and Namibia (Caprivi), and subsp. dinteri (Schinz) Exell from Angola, Namibia and Zimbabwe. Wickens (1971b) described a third subspecies, subsp. psilophyllum. The isotype of subsp. psilophyllum, Haerdi 174/87 in PRE, shows that the leaves are large, obovate, up to 80-125 $\times(32-) 65-115 \mathrm{~mm}$, with narrowly cuneate bases and are totally glabrous on both sides, except for scales, and with reticulate venation prominently raised on both sides. Specimens from the Chimanimani Mountains, Mozambique side, (T. Muller 1239 in SRGH) (Meg Coates Palgrave pers. comm.) and Tunduru Dist., Tanzania (Greenway \& Hoyle 8340 in PRE), belong to this taxon. They also match Busse 325 (HBG, K), the type of C. anacardifolium from Tanzania, but this is an unpublished manuscript name used by Adolf Englet
Wickens (1971b) placed Combretum grandifolium F.Hoffm. in synonymy under $C$. psidioides subsp. psidioides. The holotype of the former, Böhm 30a, was destroyed in World War II in Berlin, but a fragment of the isotype survived in the Zürich Herbarium. The isotype shows large leaves which match specimens in the National Herbarium (PRE) and Harare Herbarium (SRGH). These specimens are of tall trees with very rough, grey, thick, corky and deeply fissured bark, and with large leaves, $(110-) 120-240(-300) \times(80-) 130$ $160(-200) \mathrm{mm}$, densely hairy on midrib and veins, but glabrous on the areoles. The leaf bases are usually cordate to truncate, but sometimes (as in the isotype) are broadly cuneate. The fruits are up to $36 \times 28 \mathrm{~mm}$, with scales and a few scattered hairs. Young leaves are sparsely glabrous and glutinous. This form, which ranges from Tanzania, through Malawi, Zambia and Zimbabwe to Mozambique, is here proposed as a distinctive subspecies of $C$. psidioides. See key to sect. Ciliatipetala.

Nearly all specimens of the Combretum psidioides complex examined in PRE are either sterile or crimson to blood-red in fruit. An exception are collections from northern Zambia and the DRC (Milne-Redhead 2728 , Robertson 138, Robson 142, Van Meel 4158), all with flowers only. The leaves, $62-115 \times 30-48 \mathrm{~mm}$, are very thickly tomentose on both sides, whereas the midrib and lateral veins are very prominently raised on both sides, with reticulate venation inconspicuous above, the apices tapering to an acute to acuminate point or, when rounded, with a mucro, and the bases are broadly cuneate to rounded. These specimens represent a distinct entity and either represent a new subspecies of $C$. psidioides or belong to C. brachypetalum R.E.Fr.

\section{Key to species of Combretum sect. Ciliatipetala, partly from Wickens (1971b) and Exell (1978)}

1a Leaf apex usually apiculate and often twisted:

2a Leaf sparsely to densely pubescent on both surfaces; Namibia and Botswana .

$2 \mathrm{~b}$ Leaves glabrous, or only margin and midrib with hairs, glossy, glutinous and sometimes sticky when young:

3a Most leaves with apiculate apices, leaf margin flat, often with hair-tuft domatia in axils of veins below, leaf base symmetrical, reticulate venation not prominent below; upper hypanthium 2-3 mm long; petal margin ciliate; fruit 17-28 mm long; widespread

12a. C. apiculatum subsp. apiculatum

3b Only few leaves with apiculate apices, but margins often undulate, without hair-tuft domatia in axils of veins below, leaf base asymmetrical, rounded to subcordate, reticulate venation very prominent below; upper hypanthium up to $1.5 \mathrm{~mm}$ long; petal margin glabrous, not ciliate; fruit $16-19 \mathrm{~mm}$ long; Limpopo and Mpumalanga $\ldots \ldots \ldots \ldots \ldots \ldots \ldots \ldots \ldots \ldots \ldots . \ldots \ldots$. $\ldots \ldots \ldots$.trophilum

$1 \mathrm{~b}$ Leaf apex round, obtuse, acute to acuminate, rarely apiculate:

$4 \mathrm{a}$ Woody climbers .

4b Multi-stemmed shrubs or single-stemmed trees:

5a Fruit glabrous except for scales, sometimes glutinous; bark of branchlets peeling off in large \pm cylindrical or hemicylindrical pieces revealing an exposed cinnamon-red surface:

6a Leaves obovate, bases cuneate, glabrous on both sides; Tanzania and Mozambique ........... 17c. C. psidioides subsp. psilophyllum

$6 \mathrm{~b}$ Leaves oblong to oblanceolate to elliptic, bases broadly cuneate, or cordate to truncate, variously hairy on both sides; FSA region and tropical Africa:

7a Leaves usually $>110 \mathrm{~mm}$ long

$7 \mathrm{~b}$ Leaves usually $<105 \mathrm{~mm}$ long, base cuneate:

8 Leaves pubescent on reticulation below, but glabrous on areoles when mature

8 b Leaves shortly tomentose on reticulation and on areoles below when mature

17d. C. psidioides subsp. grandifolitum

17a. C. psidioides subsp. psidioides 17b. C. psidioides subsp. dinteri

$5 b$ Fruit densely to sparsely hairy, sometimes only on body or sometimes glabrous; bark of branchlets peeling off in untidy, irregular, fibrous strips or threads:

9a Scales glistening; stipe up to $8 \mathrm{~mm}$ long; northern parts of Botswana and Namibia

$9 \mathrm{~b}$ Scales not glistening; stipe up to 3(-5) $\mathrm{mm}$ long; southeastern parts of Botswana, Swaziland and South Africa:

10a Plants with silky appearance; usually multi-stemmed shrubs growing on rocks; leaves usually shorter than $60 \mathrm{~mm}$, reticulate venation not prominently raised below; fruit densely covered with longish appressed hairs over whole surface $\ldots \ldots \ldots, 14 . C$. moggii

$10 \mathrm{~b}$ Plants without silky appearance; usually single-stemmed trees; leaves usually longer than $60 \mathrm{~mm}$, reticulate venation prominently raised below; fruit very sparsely hairy mainly on the body or glabrous, but densely covered with scales . 
11. Combretum albopunctatum Suess. in Mitteilungen der Botanischen Staatssammlung München 1: 336 (1953); Exell \& Roessler: 7 (1966); Exell: 126 (1978); J.D.Carr: 29 (1988); M.Coates Palgrave: 795 (2002); Curtis \& Mannheimer: 490 (2005). Type: Namibia, Popa Falls, 1938, Volk 2105 [M sheet M0106663, lecto. e!, designated here].

Combretum sp. 2. in White: 287 (1962).

Note: Suessenguth, curator of the Botanische Staatssammlung, München from 1927-1955 (Stafleu \& Cowan 1986), mentioned two collections in the protologue of C. albopunctatum, namely Volk 2119 and 2105 , which he must have examined in the München Herbarium (M). Both syntypes were collected in Namibia, at the Popa Falls. Volk 2105 (two specimens in M) are available on the Aluka Library website and the better of the two (M0106663), which shows the characters described the best, is here selected as the lectotype. An isosyntype, Volk 2119 is housed in PRE, but unfortunately there is no specimen of the original syntype at $\mathrm{M}$ available on the Aluka Library.

Distribution: Botswana, Namibia, Zambia, Zimbabwe (Figure 9).

12a. Combretum apiculatum Sond. subsp. apiculatum in Linnaea 23: 45 (1850); Sond.: 510 (1862); Dümmer: 164 (1913); Bews: 146 (1921); Burtt Davy: 245 (1926); O.B.Mill.: 42 (1948); Exell: 3 (1961); Stace: 13 (1961); Exell \& Roessler: 7 (1966); Exell: 7 (1968); Liben: 65 (1968); Exell \& J.G.Garcia: 61 (1970); Wickens: 35 (1973); Exell: 129 (1978); Vollesen: 53 (1980); J.D.Carr: 32 (1988); Pooley: 352 (1993); A.E.van Wyk \& P.van Wyk: 328 (1997); McCleland: 456 (2002); M.Coates Palgrave: 796 (2002); Curtis \& Mannheimer: 469 (2005). Type: South Africa, [?Gauteng], Magaliesberg, Zeyher 553 (S, holo. e!; BM e!, K e!, P e!, SAM e!, TCD e!, W e!, iso.).

C. buchananii Engl. \& Diels: 40 (1899). Type: Nyassaland [Malawi], without precise locality, Buchanan 1263 (K, lecto, e!, designated here).

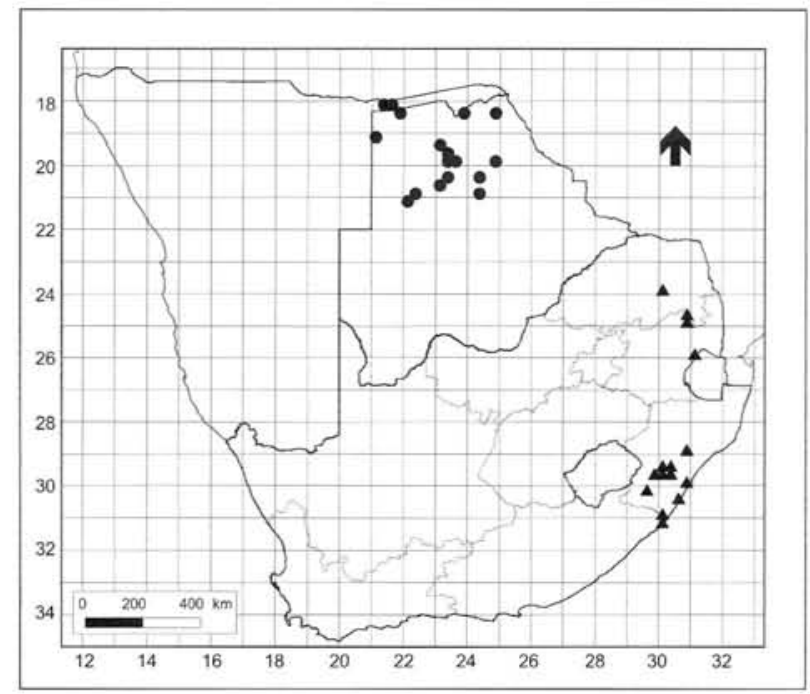

FIGURE 9.-Known distribution in FSA region of Combretum albopunctatum, - ; and C. edwardsii, $\mathbf{\Delta}$
C. apiculatum Sond. var. parvifolium Baker f.: 46 (1905). Type: Southern Rhodesia [Zimbabwe], Bulawayo, Eyles 1094 (BM, holo.; $\mathrm{SRGH}$, iso.).

C. glutinosum sensu Wood: 156 (1908), non Guill. \& Perr.: 288 (1833) ex DC.: 21 (1828).

Note: Buchanan 1263 in Kew (K) is the only extant specimen of Combretum buchananii and is chosen here as the lectotype.

Distribution: Angola, Botswana, DRC, Kenya, Malawi, Mozambique, Namibia; RSA: Gauteng, KwaZulu-Natal, Limpopo Province, Mpumalanga, NorthWest; Swaziland, Tanzania, Zambia, Zimbabwe (Figure $10)$.

12b. Combretum apiculatum Sond. subsp. leutweinii (Schinz) Exell in Mitteilungen der Botanischen Staatssammlung München 4: 3 (1961); Exell \& Roessler: 8 (1966); Exell: 19 (1968); Exell: 195 (1970); Exell: 132 (1978); Curtis \& Mannheimer: 471 (2005). Type: [Namibia], Otjiwarongo, Waterberg, Mar. 1899, Dinter 413 (Z, holo. e!).

\section{C. leutweinii Schinz: 878 (1901).}

C. kwebense N.E.Br: 111 (1909); O.B.Mill.: 43 (1948). Type: [Botswana], Ngamiland, Kwebe Hill, Lugard 48 (K, holo. e!).

Distribution: Botswana, Malawi, Mozambique, Namibia, Zambia, Zimbabwe (Figure 11).

13. Combretum edwardsii Exell in Boletim da Sociedade Broteriana, sér. 2, 42: 19 (1968); Verhoeven \& Van der Schijff: 39 (1975); J.D.Carr: 59 (1988); Pooley: 354 (1993); McCleland: 460 (2002); M.Coates Palgrave: 800 (2002). Type: South Africa, [KwaZuluNatal], Impendle Dist., Lundy's Hill, upper edge of Umkomaas Valley, Edwards 3147 (PRE, holo.!; K e!, $\mathrm{NH}$ e!, NU e!, iso.).

Distribution: RSA: KwaZulu-Natal, Limpopo Province, Mpumalanga (Figure 9).

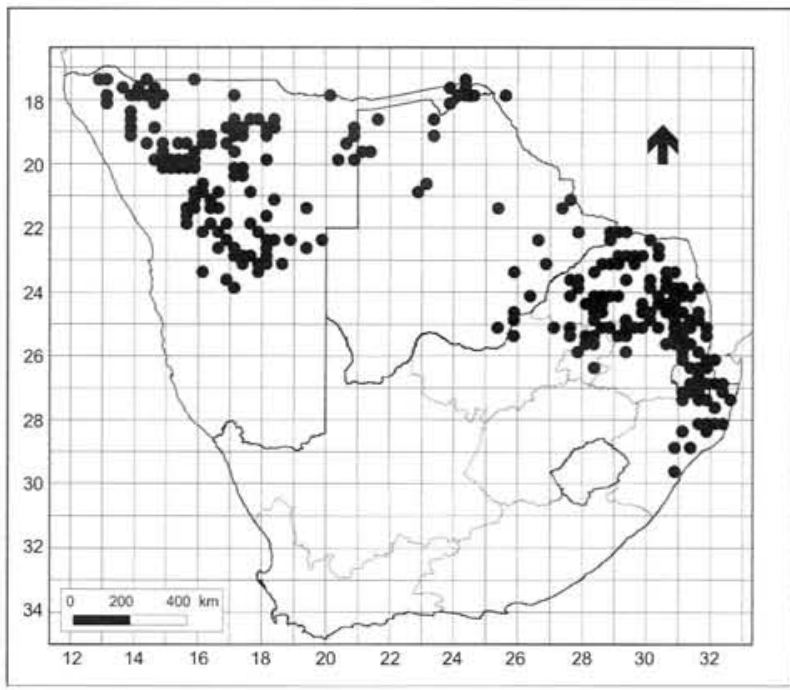

FIGURE 10.- Known distribution in FSA region of Combretum apiculatum subsp. apiculatum. 
14. Combretum moggii Exell in Boletim da Sociedade Broteriana, sér. 2, 42: 21 (1968); J.D.Carr: 98 (1988); Hennessy: t. 2027 (1991a); McCleland: 464 (2002); M.Coates Palgrave: 805 (2002). Type: South Africa, [Mpumalanga], Middelburg Dist., Olifants River gorge, Hoornsnek, Farm Slaghoek 126, 20 miles [32 km] NW, Oct. 1953, Mogg 22400 (PRE, holo.!; BM e!, $\mathrm{J}, \mathrm{K} \mathrm{e}$ !, iso.).

Distribution: RSA: Gauteng, KwaZulu-Natal, Limpopo Province, Mpumalanga; Swaziland (Figure 12).

15. Combretum molle R.Br. ex G.Don in Transactions of the Linnean Society of London 15: 431 (1827); F.W.Andrews: 201 (1950); Exell: 7 (1968); Liben: 67 (1968); Exell \& J.G.Garcia: 62 (1970); Wickens: 33 (1973); Exell: 127 (1978); Vollesen: 53 (1980); Liben: 18 (1983); J.D.Carr: 102 (1988); Pooley: 356 (1993); Thulin: 249 (1993); Vollesen: 118 (1995); A.E.van Wyk \& P.van Wyk: 334 (1997); McCleland: 466 (2002); M.Coates Palgrave: 806 (2002). Type: Ethiopia, without locality, Salt s.n. (BM, holo. e!).

C. velutinum DC.: 20 (1828). Type: Guinea, collector unknown ( $\mathrm{P}$, holo. e!).

C. ferrugineum A.Rich.: 267 (1848). Type: Ethiopia, Selassaquilla, Schimper 767 (P, holo. e!; BR e!, K, W e!, iso.).

C. gueinzii Sond.: 43 (1850); Sond.: 509 (1862); Engl. \& Diels: 38 (1899); Dümmer: 116 (1913); Bews: 147 (1921); F.W.Andrews: 202 (1950). Type: South Africa, [KwaZulu-Natal], Port Natal [Durban], 'in silvis', Gueinzius 567 (S, holo. e!; K e!, SAM e!, TCD e!, iso.).

C. holosericeum Sond.: 44 (1850); Sond.: 510 (1862); M.A.Lawson: 430 (1871); Dümmer: 116 (1913); Burtt Davy: 247 (1926); O.B.Mill.: 43 (1948). C. gueinzii Sond. var. holosericeum (Sond.) Exell ex Rendle: 93 (1932). Type: South Africa, [?Gauteng], 'Magalisberg', Zeyher 575 (S, holo. e!; BM e!, K, fragment e!, P, fragment e!, PRE!, SAM e!, W e!, WU, fragment e!, Z e!, iso.).

C. splendens Engl.: 289 (1895); Engl. \& Diels: 37, t. 11/D (1899). C. gueinzii Sond. subsp. splendens (Engl.) Exell ex Brenan: 137 (1949). Type: Nyassaland [Malawi], locality unknown, Buchanan 859 (K, lecto. e!, designated here).

C. welwitschii Engl. \& Diels: 40 (1899). Type: Angola, Cuanza Norte, Golungo Alto, near banks of rivulet Quiposa, not far from Canguerasange, Welwitsch 4318 [LISU, lecto. e!, designated by Garcia (1961); BM e!, BR e!, G e!, P e!, isolecto.].

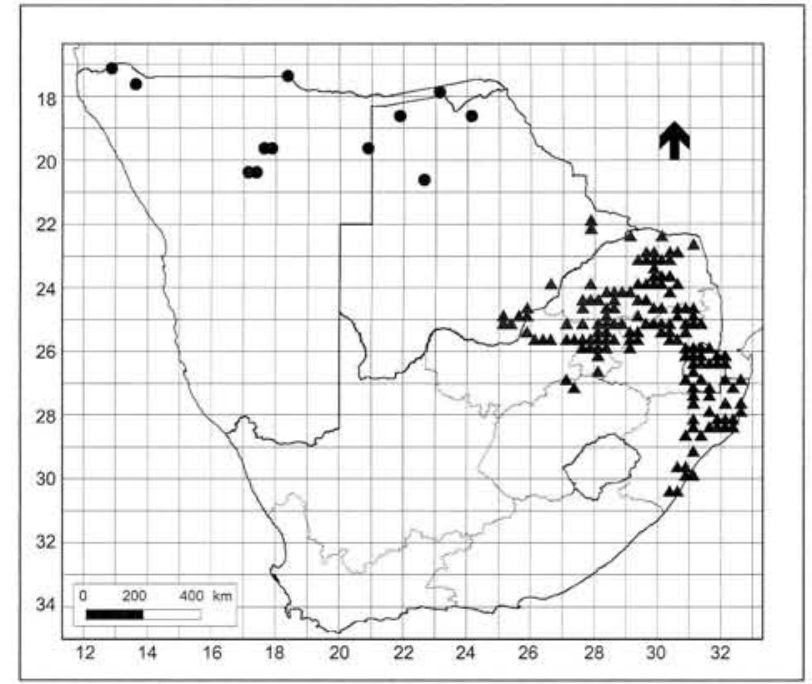

C. galpinii Engl. \& Diels: 41 (1899); Dümmer: 147 (1913); Burtt Davy: 246 (1926). Type: South Africa, [Mpumalanga], Barberton Dist., Avoca, near Barberton, Galpin 112 (Z, lecto. e!, designated here; BOL, K e!, NH e!, PRE!, SAM e!).

C. obtusatum Engl. \& Diels: 58 (1899). Type: Angola, Lubango, Huila, Antunes A50,61 [BM fragment, lecto. e!, designated by Exell \& Garcia (1970); COI, isolecto.].

C. dekindtianum Engl.: 136 (1902). Type: Angola, Lubango, Huila, Dekindt 51 [LUA, lecto., designated by Exell \& Garcia (1970)].

C. arengense Sim: 62, t. 63, fig. B (1909). Type: Mozambique, Maganja da Costa, Sim 5916 (probably = Sim 20902) (NU, holo. e!; PRE, iso.!).

C. ellipticum Sim: 63, t. 63, fig. D (1909). Type: Mozambique, without precise locality, $\operatorname{Sim} 6068$ (NU, holo. e!; K e!, PRE!, iso.).

Note: in their protologue of Combretum galpinii, Engler \& Diels (1899) mentioned Galpin 112 in the Zürich Herbarium (Z) and Wood 6547 in Berlin Herbarium (B). The Galpin specimen in $\mathrm{Z}$ is the only specimen that survived. It was examined by Engler \& Diels and is therefore chosen as lectotype.

Engler (1895) cites syntypes from Tanzania and Malawi in his protologue of C. splendens, but only an isotype of Buchanan survived in Kew, which is here chosen as the lectotype.

Distribution: Benin, Botswana, Burkina Faso, Burundi, Cameroon, Central African Republic, Chad, Cote d'Ivoire, DRC, Ethiopia, Ghana, Guinea, Guinea-Bissau, Kenya, Malawi, Mozambique, Nigeria; RSA: Free State, Gauteng, KwaZulu-Natal, Limpopo Province, Mpumalanga, North-West; Rwanda, Saudi Arabia, Sierra Leone, Somalia, Sudan, Swaziland, Tanzania, Togo, Uganda, Yemen, Zambia, Zimbabwe (Figure 11).

16. Combretum petrophilum Retief in Bothalia 16: 44 (1986); J.D.Carr: 124 (1988); McCleland: 468 (2002); M.Coates Palgrave: 809 (2002). Type: South Africa, [Limpopo Province], Strydom Tunnel, Oct. 1982, Carr 203 (PRE, holo.!; K, MO e!, iso.).

Distribution: RSA: Limpopo Province (Figure 13).

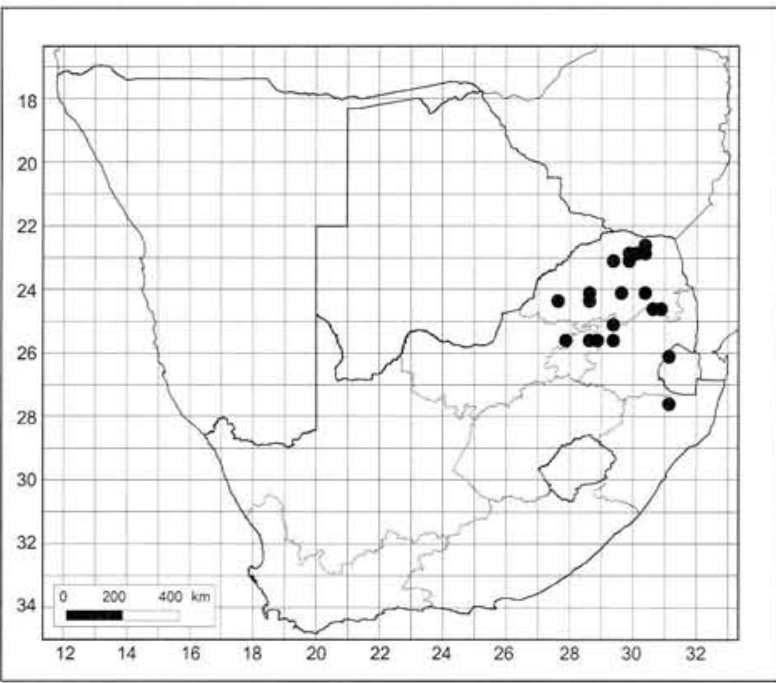

FIGURE 12.-Known distribution of Combretum moggii. 
17. Combretum psidioides Welw. in Annaes Conselho Ultramarino, sér. 1, 24: 249 (1856); Exell: 5 (1961); Exell \& Roessler: 10 (1966); Exell: 8 (1968); Exell \& J.G.Garcia: 64 (1970); Wickens: 36 (1971b); Wickens: 37 (1973); Exell: 133 (1978); J.D.Carr: 135 (1988); A.E.van Wyk \& P.van Wyk: 336 (1997); M.Coates Palgrave: 810 (2002); Curtis \& Mannheimer: 484 (2005). Type: Angola, 'in dumetosis interioris Provinciae Angolensis, rarior avis. Arbuscula elegans filiis maximis, habitu exacte Psidiorum. Quicuze', Welwitsch 4378 (LISU, holo. e!; BM, BR e!, COI, K e!, P e!, iso.).

17a. subsp. psidioides

Distribution: Angola, Botswana, Namibia, Zimbabwe (Figure 13).

17b. subsp. dinteri (Schinz) Exell in Mitteilungen der Botanischen Staatssammlung München 4: 3 (1961); Exell \& Roessler: 10 (1966); Exell \& J.G.Garcia: 66 (1970); Wickens: 38 (1971b); Exell: 135 (1978); J.D.Carr: 135 (1988). Type: [Namibia], Hereroland, Apr. 1899, Dinter 580 (Z, holo. e!).

\section{C. dinteri Schinz: 877 (1901).}

C. quirirense Engl. \& Gilg: 318 (1903). Type: Angola, Bié, Quiriri River, Baum 722 [B, holo.*; BM, lecto. e!, designated by Exell \& Garcia (1970); BR e!, COI, E e!, HBG e!, K, S e!, W e!, Z e!, isolecto.].

C. omahekae Gilg \& Dinter ex Engl.: 698 (1921). Type: [Namibia], Omaheke, 'bei Otjituo und Naitsas' (type not zaced).

Distribution: Angola, Namibia, Zambia, Zimbabwe (Figure 13).

17c. subsp. psilophyllum Wickens in Kew Bulletin 26: 39 (1971b); Wickens: 38 (1973). Type: Tanzania, Ulanga Dist., Ifakara, Haerdi 174/87 (K, holo. e!; EA e!, PRE!, iso.).

Distribution: probably Mozambique, and Tanzania.

17d. subsp. grandifolium (F.Hoffm.) Jordaan, stat. nov.

C. grandifolium F.Hoffm. in Beiträge zu Kenntnis der Flora von Central-Ost-Afrika: 29 (1889); Engl.: 289 (1895); Engl. \& Diels: 39

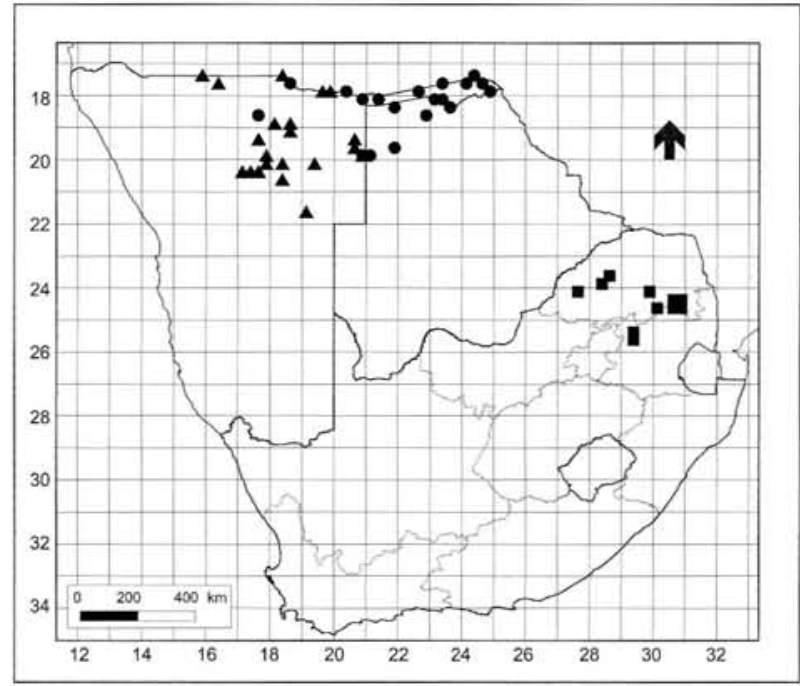

FIGURE 13,- Known distribution in FSA region of Combretum petrophilum, $\mathbf{\square}$; C. psidioides subsp. psidioides, - ; and $C$. psidioides subsp. dinteri, $\boldsymbol{\Lambda}$
(1899); Engl.: 698 (1921). Type: Tanganyika [Tanzania], Mpanda Dist., Pa-Kabombue, Böhm 30a (B, holo.†; Z fragment, iso. e!).

Distribution: Malawi, Mozambique, Tanzania, Zambia, Zimbabwe.

\section{GROUP 2}

Species with large scales, usually larger than $100 \mu \mathrm{m}$, divided by many radial and tangential walls (Figure 2 ).

VI. Combretum sect. Hypocrateropsis Engl. \& Diels (1899); Exell: (1968); Stace: 135 (1969); Exell: $105(1978)$

Species in this section are woody climbers, scramblers or sometimes trees, usually multi-stemmed and without spine-tipped lateral branches. The upper hypanthium of the flowers is almost flat and little developed and the petals are linear-elliptic and glabrous. The scales on the leaves are the largest in Combretum, mostly over $150 \mu \mathrm{m}$, and are circular, divided by many radial and tangential walls.

Engler \& Diels (1899) described two species: 1, Combretum tenuipes from a plant collected at Low's Creek in the Barberton District and 2, C. padoides from a plant collected in Mozambique. C. tenuipes was subsequently placed in synonymy with $C$. padoides by Exell (1968, 1970, 1978), Wickens (1973), Carr (1988) and Rodman (1990). Rogers (1989) conducted chemotaxonomic studies on the leaves of $C$. padoides (his 'coastal form') and C. temuipes (his 'inland form'). He found significant differences between the oxidation states of some of the compounds isolated from coastal and inland trees and suggested that the differences could be due to geographic or genetic factors and needed to be investigated further. Rogers's samples of his 'inland species' came from a plant growing in the Pretoria National Botanic Garden, which is without any doubt $C$. tenuipes. Samples of his 'coastal species' came from a tree in Durban, grown from seed originating from a tree growing in the National Botanic Garden, Harare, Zimbabwe. C. tenuipes is confined to the Barberton Centre of Endemism

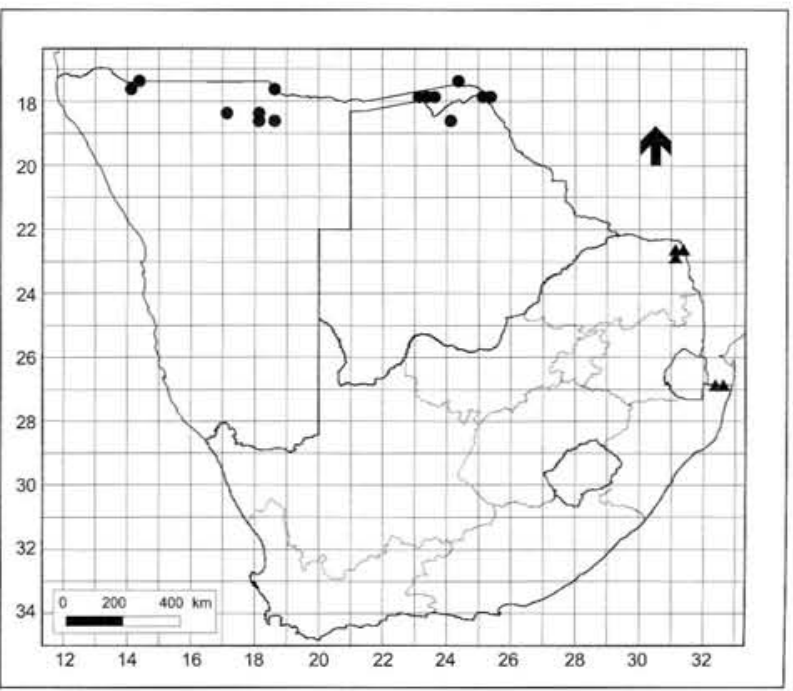

FIGURE 14.-Known distribution in FSA region of Combretum celastroides subsp. celastroides, and C. patelliforme, 
(Van Wyk \& Smith 2001), whereas C. padoides grows in eastern tropical Africa, from Kenya southwards to Tanzania, Malawi, Zambia, eastern Zimbabwe and Mozambique, as well as the DRC, and just enters South Africa in the northernmost part of Limpopo Province. Pooley (1993) included C. padoides as occurring in KwaZuluNatal and the accompanying photos to illustrate the species were taken in the Pretoria National Botanical Garden; this means that the photos depict $C$. tenuipes. Combretum padoides has not yet been recorded in KwaZulu-Natal, but there is a new, undescribed species of Combretum growing as a climber in the sand forest of Maputaland with which it may be confused. However, this new species does not belong to sect. Hypocrateropsis. Combretum tenuipes and $C$. padoides are here reinstated as separate species since there are several differences, including geographical, molecular (Maurin et al. 2010) and morphological ones (see the key) to distinguish between them.

Exell (1968) described a third subspecies of Combretum celastroides, namely $C$. celastroides subsp. orientale based on a plant from Mozambique, collected by Schlechter at Maputo [Delagoa Bay]: Schlechter 11957. This is also one of the syntypes of C. patelliforme Engl. \& Diels (1899). The other syntype of $C$. patelliforme is from Angola, namely Antunes A155, which was destroyed in World War II, but this belongs to subsp. celastroides. The two subspecies of C. celastroides in the FSA region, the typical subspecies and subsp. orientale, are quite different morphologically, and this is supported by molecular evidence (Maurin et al. 2010 ) and by the fact that the two taxa are geographically disjunct. Hence $C$. celastroides subsp. orientale is elevated to species level as C. patelliforme Engl. \& Diels. See the key for differences between it and subsp. celastroides. C. celastroides subsp. laxiflorum (Welw. ex M.A.Lawson) Exell has larger flowers than the other subspecies, the leaves are nearly glabrous, and it is usually a tree. It occurs in Zambia, Angola, Tanzania and DRC.

Key to species of Combretum sect. Hypocrateropsis based on Exell (1978)

la Disc glabrous:

2a Leaves pubescent on entire leaf surface below; disc up to $4 \mathrm{~mm}$ diam.; fruit $\pm 18-20 \times 17-22 \mathrm{~mm}$; peg $\pm 1.0-2.5$ $\mathrm{mm}$ long; Caprivi, Botswana .......... 18. C. celastroides

$2 \mathrm{~b}$ Leaves almost glabrous below (except for hair-tuft domatia in axils of veins below); disc $2.0-2.5 \mathrm{~mm}$ diam.; fruit \pm $15 \times 15 \mathrm{~mm}$; peg up to $1 \mathrm{~mm}$ long; Limpopo Province, KwaZulu-Natal ................... 20. C patelliforme

\section{lb Disc pilose:}

3a Ultimate twigs hairy; leaves narrowly elliptic, usually longer than $55 \mathrm{~mm}$, margin flat, principal lateral veins in 土 5-8 pairs; fruit usually larger than $17 \times 17 \mathrm{~mm}$; Limpopo Province .................... 19. C. padoides

$3 \mathrm{~b}$ Ultimate twigs glabrous; leaves ovate, usually shorter than $45 \mathrm{~mm}$, margin markedly wavy, principal lateral veins in 3(4) pairs; fruit usually $15 \times 15 \mathrm{~mm}$ or smaller; Mpumalanga and Swaziland (Barberton Centre of Endemism)

21. C. tenuipes

18. Combretum celastroides Welw. ex M.A.Lawson in Flora of tropical Africa 2: 422 (1871); Engl. \& Diels: 12 (1899); O.B.Mill.: 42 (1948); F.White: 284 (1962); Exell \& Roessler: 8 (1966); Exell: 16 (1968); Exell: 168 (1970); Exell \& J.G.Garcia: 50 (1970); Wickens:17 (1973); Exell:
107 (1978); J.D.Carr: 45 (1988); M.Coates Palgrave: 798 (2002); Curtis \& Mannheimer: 472 (2005). Type: Angola, Huila, Welwitsch 4370 [LISU, lecto., designated by Exell \& Garcia (1970); BM e!, BR e!, COI, K e!, P e!, PRE!, isolecto.].

C. patelliforme Engl. \& Diels: 12, t. 1, fig. C (1899) pro parte quoad specim. Antunes Al55 (B⿱宀).

Distribution: Angola, Botswana, Mozambique, Namibia, Tanzania, Zambia, Zimbabwe (Figure 14).

19. Combretum padoides Engl. \& Diels in Monographieen afrikanischer Pflanzenfamilien und Gattungen 3: 13 (1899); Exell: 7 (1968); Liben: 40 (1968); Exell: 168 (1970); Wickens: 17 (1973): Exell: 107 (1978); Vollesen: 53 (1980); J.D.Carr: 17 (1988); Thulin: 248 (1993); Pooley: 354 (1993); McCleland: 468 (2002), pro parte; M.Coates Palgrave: 808 (2002). Type: Mozambique, Zambezi, Boroma, Menyharth 878 [Z, lecto. e!, designated by Exell (1970); K e!, WU e!, isolecto.].

C. homblei De Wild.: 196 (1914). Type: Democratic Republic of the Congo, Katanga, Kapiri Valley, 1913, Homblé 113 (BR, holo. e!; $\mathrm{BM}$, fragment, iso. e!).

C. mimutiflorum Exell: 245 (1930). Type: Tanganyika [Tanzania], Kilosa Dist., Kipera [Kipela], Oct. 1921, Swynnerton s.n. (BM, holo. e!).

Distribution: DRC, Kenya, Malawi, Mozambique, RSA: Limpopo Province; Somalia, Tanzania, Zambia, Zimbabwe (Figure 15).

20. Combretum patelliforme Engl. \& Diels in Monographieen afrikanischer Pflanzenfamilien und Gattungen 3: 12, t. 1, fig. C (1899); Dümmer: 183 (1913). Type: Mozambique, Delagoa Bay [Maputo], Schlechter 11957 [BM, lecto. e!, designated by Exell (1968); BOL, BR e!, COI, E e!, HBG e!, K e!, L e!, MO e!, P e!, PRE!, SAM, WAG e!, Z e!, iso.].

C. celastroides Welw. ex M.A.Lawson subsp. orientale Exell: 16 (1968); Wickens: 17 (1973); Exell: 107 (1978); J.D.Carr: 45 (1988); Pooley: 354 (1993); McCleland: 458 (2002).

Note: Engler \& Diels (1899) described three species in this section, Combretum patelliforme, C. padoides and $C$. tenuipes. In the protologue of $C$. patelliforme, two syntypes are cited: Antunes Al55 from Angola and Schlechter 11957 from Mozambique. The specimen from Angola belongs now to $C$. celastroides subsp. celastroides and Mozambique specimen to $C$. patelliforme, pro parte. Exell (1968) reduced this name to subspecific level and used a new epithet, namely orientale and lectotypified this name with the Schlechter specimen. Once this taxon is elevated now to species level the old epithet patelliforme must be used, because no name has priority outside its rank according to the International Code of Botanical Nomenclature (Vienna Code): 11.2 (McNeill et al. 2006).

Distribution: Mozambique, RSA: KwaZulu-Natal, Limpopo Province; Tanzania, Zambia, Zimbabwe (Figure 14).

21. Combretum tenuipes Engl. \& Diels in Monographieen afrikanischer Pflanzenfamilien und Gattungen 3: 13, t. 3, fig. b (1899); Dümmer: 182 (1913); Burtt 


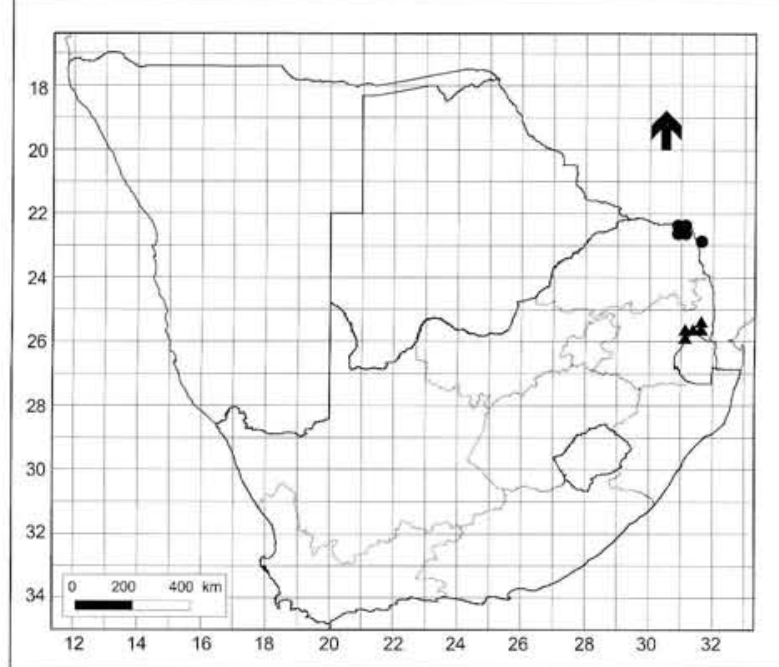

FIGURE 15.- Known distribution in FSA region of Combretum padoides,

Davy: 246 (1926). Type: South Africa, [Mpumalanga], Barberton Dist., Louws Creek, Galpin 885 (Z, holo. e!; BOL, $\mathrm{K}$ e!, PRE!, SAM e!, iso.).

Distribution: Mpumalanga and probably Swaziland (Figure 15).

VII. Combretum sect. Metallicum Exell (1968); Stace: 145 (1969); Exell: 179 (1970); Exell: 117 (1978); Wickens: 23 (1973)

Species in this section are nearly always glutinous, especially when young. The scales on the leaves are usually extensively divided by many radial and tangential walls to give rise to $\pm 10-40$ marginal cells. The disc has a free, pilose margin. The fruit are glabrous to densely hairy in Combretum collimum subsp. suluense, and are usually somewhat 'metallic' in colour.

Okafor (1967) recognized four subspecies of Combretum collinum in the FSA region. Carr (1988) regarded the separation of $C$. collinum into subspecies as unjustified because of the largely overlapping geographical distribution patterns of these four subspecies. Here, however, we uphold the four subspecies as recognized by Okafor (1967). C. coriaceum, described by Schinz (1888), is conspecific with $C$. gazense and is the oldest validly published name for this subspecies but was not used by Okafor when he reduced this taxon to subspecific rank.

There are four synonyms of subsp. suluense described earlier than 1899, but Okafor chose to use the name suluense over the other four (C. fischeri, C. brosigianum, C. fulvotomentosum and C. schinzii). Type material for C. fischeri, C. brosigianum and C. fulvotomentosum was destroyed and they could be considered to be uncertain names. There is, however, an isotype of $C$. schinzii in the Zürich Herbarium (Z) described in 1899 that could serve as a lectotype. It seems, however, that this taxon rather belongs to $C$. collinum subsp. ondongense (1899) and not to $C$. collinum subsp. suluense as stated by Rod$\operatorname{man}(1990)$.
Pooley (1993) gives a group of records for Combretum collimum subsp. suluense from around False Bay and Mkuze Game Reserve, but specimens growing in these sand forest areas belong to an undescribed species. There is, however, one specimen in the KwaZulu-Natal Herbarium collected in the mountains north of Vryheid which gives the distribution for subsp. suluense as far north as Kenya and southwards as far south as Swaziland and far northern KwaZulu-Natal. C. collinum subsp. ondongense (Engl. \& Diels) Okafor is confined to the Kalahari sands of Angola, Namibia, Botswana, Zambia and the eastern fringe of Zimbabwe, and has not been recorded in South Africa. The holotype of subsp. taborense is based on Stuhlmann 506, collected in Tabora, Tanzania, but was destroyed in World War II and no isotypes seem to exist. Okafor was confident enough to use this name despite the lack of type material. In the absence of good material from Tanzania in the National Herbarium in Pretoria, we have refrained from selecting a neotype for this taxon.

\section{Key to subspecies of Combretum collinum}

Ia Leaves densely grey-hairy below; fruit glabrous; Namibia, Botswana, Limpopo Province and Mpumalanga ........

$\ldots \ldots \ldots \ldots \ldots \ldots . \ldots .22 a$. . C. collinum subsp. gazense

1b Leaves glabrous below, except for hairs in axils of veins; fruit glabrous or hairy:

2a Fruit densely hairy, red scales conspicuous

$\ldots \ldots \ldots \ldots \ldots \ldots .22 \mathrm{c}$, C. collinum subsp. suluense 2b Fruit glabrous:

3a Leaf apices acute to acuminate to apiculate, lamina silvery below, with conspicuous darker venation; Limpopo Province and Mpumalanga...$\ldots \ldots \ldots \ldots$. 22d. C. collinum subsp. taborense

$3 b$ Leaf apices rounded to subacute, lamina yellowish below, without conspicuous darker venation; Namibia, Botswana ......... 22b. C. collimum subsp. ondongense

22a. Combretum collinum Fresen. subsp. gazense (Swynn. \& Baker f.) Okafor in Boletim da Sociedade Broteriana, sér. 2, 41: 145 (1967); Exell: 182 (1970); Wickens: 27 (1973); Coates Palgrave: 665 (1977); Exell: 120 (1978); J.D.Carr: 51 (1988); McCleland: 458 (2002); M.Coates Palgrave: 799 (2002); Curtis \& Mannheimer: 474 (2005). Type: Mozambique, Gazaland, between upper Buzi and Mount Umtereni, Swynnerton 587 (BM, holo. e!; $\mathrm{K}$ e!, Z e!, iso.).

C. gazense Swynn. \& Baker f.: 68 (1911); Burtt Davy: 248 (1926); O.B.Mill.: 42 (1948); Codd: 129 (1951). C. mechowianum O.Hoffm. subsp. gazense (Swynn. \& Baker f.) Duvign.: 81 (1956); Liben: 77 (1968).

C. coriaceum Schinz: 247 (1888); Dinter: 169 (1919); O.B.Mill.: 42 (1948). Type: [Namibia], Ngamigebiet, 1888, Fleck 422a (Z, holo. $\mathrm{e} ! \mathrm{K}$, iso. e!).

C. bajonense Sim: 63, t. 63 (1909). Type: Mozambique, Magenja da Costa, 1908, Sim 5715 (renumbered as 20901) (PRE, holo.!; NU, iso.).

C. eylesii Exell: 170 (1939). Type: [Zimbabwe], Salisbury [Harare], Eyles 849 (BM, holo. e!; $\mathrm{K}$, iso. e!).

Distribution: Botswana, DRC, Malawi, Mozambique, Namibia; RSA: Limpopo Province, Mpumalanga; Tanzania, Zambia, Zimbabwe (Figure 16).

22b. subsp. ondongense (Engl. \& Diels) Okafor in Boletim da Sociedade Broteriana, sér. 2, 41: 147 (1967); Exell: 120 (1978); J.D.Carr: 50 (1988); M.Coates Pal- 


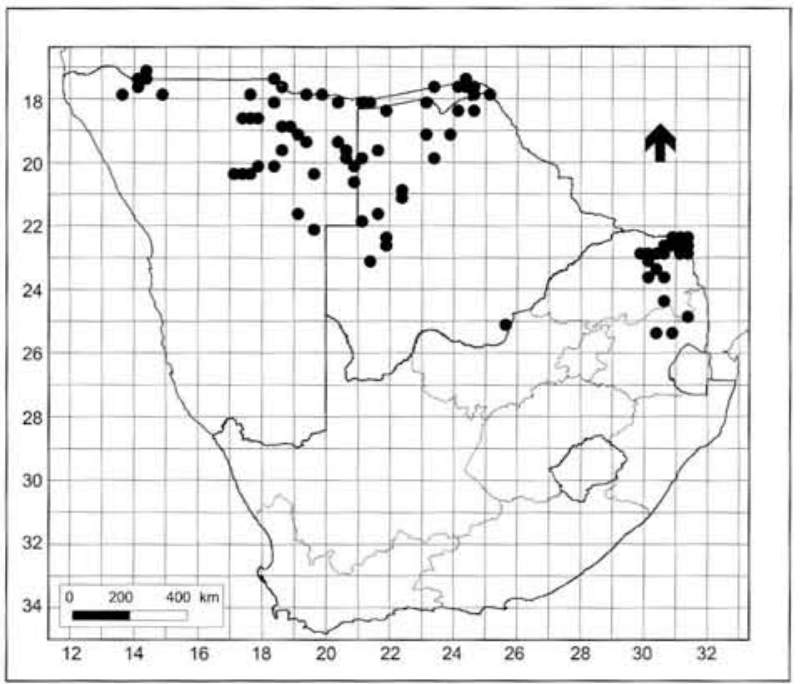

FIGURE 16.-Known distribution in FSA region of Combretum collinum subsp. gazense.

grave: 799 (2002); Curtis \& Mannheimer: 474 (2005). Type: [Namibia], 'Amboland zwischen Ondonga und Unkussyama', July 1897, Rautanen 234 (HBG, holo.; $\mathrm{BM}$, fragment e!, K e!, Se!, WU e!, Z e!, iso.).

C. ondongense Engl. \& Diels: 56 (1899).

C. schinzii Engl. ex Engl. \& Diels: 54 (1899). Type: Namibia, Onkumbi, Sep. 1885, Schinz 1037 (B, holo.†; Z, iso. e!).

Distribution: Botswana, Namibia, Zimbabwe (Figure 17).

22c. subsp. suluense (Engl. \& Diels) Okafor in Boletim da Sociedade Broteriana, sér. 2, 41: 143 (1967); Wickens: 28 (1973); Exell: 120 (1978); Vollesen: 53 (1980); J.D.Carr: 51 (1988); McCleland: 458 (2002); M.Coates Palgrave: 799 (2002); Curtis \& Mannheimer: 474 (2005). Type: Swaziland, hill slopes, Horo Mine, Dec. 1890-1894, Galpin 1264 (B, holo.†; BOL, K e!, NH, PRE!, SAM e!, Z e!, iso.).

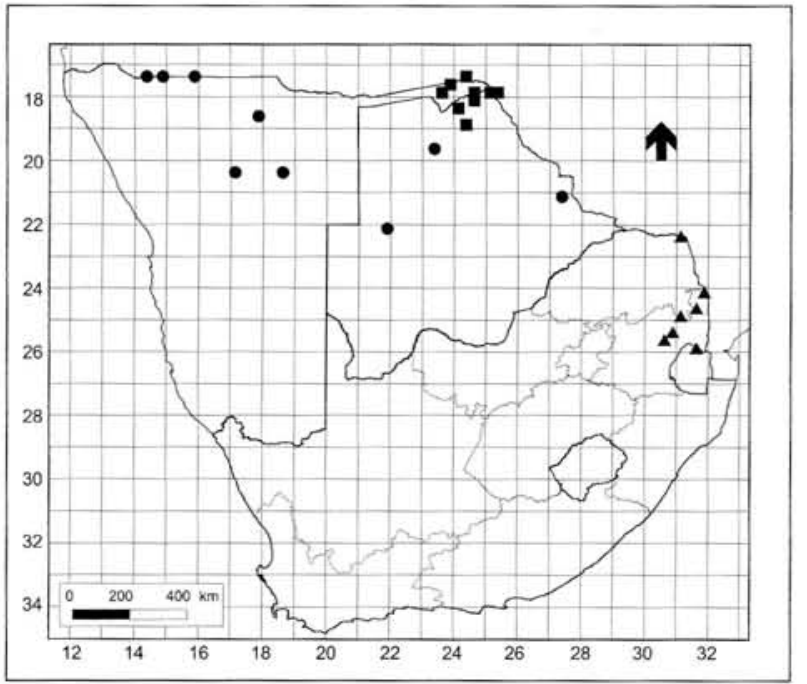

FIGURE 17.-Known distribution in FSA region of Combretum collinum subsp. ondongense, - and C. collinum subsp. taborense, $\boldsymbol{\Delta}$; and $C$. elaeagnoides,
C. suluense Engl. \& Diels: 54 (1899); Dümmer: 183 (1913); Burtt Davy: 248 (1926); O.B.Mill.: 43 (1948).

C. junodii Dümmer: 183 (1913); Bews: 147 (1921). Type: South Africa, [Limpopo Province], hills, Shilouvane, Junod 613 (K, holo. e!; PRE!, $Z$ e!, iso.).

C. griseiflorum S.Moore: 227 (1921); Burtt Davy: 246 (1926); O.B.Mill.: 43 (1948). Type: South Africa, [Mpumalanga], Nelspruit, Breyer s.n. sub Rogers 24018 (BM, holo. e!)

C. angustilanceolatum Engl.: 702 (1921). Type: Mozambique, Lower Umswirizwi River, Swynnerton 45 (B, holo.†; BM, lecto. e!, designated here; $\mathrm{K}$, isolecto. e!).

C. makindense Gilg ex Engl.: 703 (1921). Type: Kenya, Machakos Dist., Kibwezi, Makinde Steppe, Scheffler 210 (B, holo.†; K, lecto. e!, designated here; BM, E e!, HBG e!, P e!, PRE!, WAG e!, Z e!, isolecto.).

C. millerianum Burtt Davy: 279 (1921). Type: Swaziland, Buckham's to Forbes' Coal Mine, June 1911, Burtt Davy 10681 (BOL, holo.; $\mathrm{K}$, iso. e!).

Note: the holotype of Combretum angustilanceolatum was destroyed and from the two extant isotypes in BM and $\mathrm{K}$, the first-mentioned specimen is chosen as lectotype, because it is the better one of the two.

The holotype, Scheffler 210, of C. makindense was destroyed and the Kew specimen, the best of all the duplicates, is the only one seen by Wickens (1968) and identified by him. It is here chosen as lectotype.

Distribution: Angola, Kenya, Malawi, Mozambique, ?Namibia; RSA: Limpopo Province, Mpumalanga: Swaziland, Tanzania, Zambia, Zimbabwe (Figure 17).

22d. Combretum collinum Fresen. subsp. taborense (Engl.) Okafor in Boletim da Sociedade Broteriana, sér. 2, 41: 144 (1967); Exell: 182 (1970); Wickens: 26 (1973); Exell: 120 (1978); Vollesen: 53 (1980); J.D.Carr: 51 (1988); McCleland: 460 (2002); M.Coates Palgrave: 800 (2002). Type: Tanzania, Tabora, Stuhlmann 506 (B, holo. $\dot{\dagger})$.

C. taborense Engl.: 290 (1895). C. mechowiamum O.Hoffm. subsp. taborense (Engl.) Duvign.: 80 (1956); Liben: 76 (1968).

C. goetzeniamum Diels: 500 (1907). Type: Tanzania, Dondoland, between Kilwa and Likemba, Busse 570 (B, holo.广; EA, lecto., designated here; $\mathrm{BM}$, fragment, isolecto. e!).

C. psammophilum Diels: 502 (1907). Type: Tanzania, Lindi, Ruaha, Busse 1122 (B, holo.;; EA, lecto. e!, designated here; BM, isolecto.).

C. burttii Exell: 169 (1939). Type: Zambia, 25 miles [40 km] from Kassama on road to Issaka, near Malole Mission, Burtt 5951 (BM, holo. e!; BR e!, EA e!, K, iso.).

Note: Diels (1907) described two species, Combretum goetzenianum and C. psammophilum, based on Busse's specimens he collected in Tanzania. Both species proved to be $C$. collinum subsp. taborense. The holotypes of both names was destroyed and the isotypes in the East African Herbarium (EA) in Kenya are chosen here as lectotypes. The material in BM are merely fragments.

Distribution: DRC, Malawi, Mozambique; RSA: Limpopo Province, Mpumalanga; Tanzania, Zambia, Zimbabwe (Figure 17). 
VIII. Combretum sect. Breviramea Engl. \& Diels (1899); Stace: 148 (1969); Exell: 199 (1970); Exell: 136 (1978)

Combretum hereroense Schinz belongs to this section. It often has divaricately branched stems; leaves mostly with only 3 or $4(5)$ pairs of principal lateral veins; 4-merous flowers; upper hypanthium campanulate to infundibuliform; petals spathulate to broadly obovate or obovate or subcircular and glabrous; disc with a pilose free margin; fruit up to $35 \mathrm{~mm}$ long and glabrous; scales very densely packed, contiguous, sometimes hidden by dense indumentum of combretaceous hairs on leaves below, (50-)75-120(-160) $\mu \mathrm{m}$ diam., irregular in outline, delimited usually by 8 primary radial walls with up to 8 tangential and up to 4 partial radial walls.

Combretum hereroense is extremely variable in leaf shape and indumentum and sometimes in the size of the fruit. The indumentum varies from densely tomentose to nearly glabrous. Wickens (1971a) subdivided C. hereroense into three subspecies, and subsp. hereroense into two varieties on account of their hairiness. Only the typical subspecies occurs in our area. We do not recognize these varieties.

Combretum hereroense, $C$. imberbe and $C$. elaeagnoides are clearly related according to the molecular analysis by Maurin et al. (2010), although currently placed in three different sections. They are characterized by 4-merous flowers in dense often subcapitate axillary spikes, a glabrous disc and lepidote fruit. Leaves in all these species are densely lepidote with scales contiguous or overlapping, silver or golden or rust-brown with cells divided by numerous radial and tangential walls. All three species are deciduous trees, although $C$. elaeagnoides has a tendency to scramble. Young stems of $C$. imberbe have short, opposite, spine-tipped lateral shoots.

23. Combretum hereroense Schinz subsp. hereroense in Verhandlungen des Botanischen Vereins der Provinz Brandenburg 30: 245 (1888); Engl. \& Diels: 63 (1899); Dümmer: 201 (1913); Exell \& Roessler: 8 (1966); Exell: 8 (1968); Exell \& J.G.Garcia: 56 (1970); Wickens: 411 (1971a); Wickens: 40 (1973); Exell: 138 (1978); Vollesen: 53 (1980); J.D.Carr: 77 (1988); Pooley: 356 (1993); Vollesen: 118 (1995); A.E.van Wyk \& P.van Wyk: 332 (1997); McCleland: 462 (2002); M.Coates Palgrave: 803 (2002); Curtis \& Mannheimer: 478 (2005). Type: South West Africa [Namibia], Otjovazandu, Schinz 431 (Z, holo. e!; B, iso. †).

C. eilkeramum Schinz: 246 (1888); Engl. \& Diels: 61 (1899); O.B.Mill.: 42 (1948). Type: South West Africa [Namibia], Kunene, Schinz 420 (Z, holo. e!).

C. transvaalense Schinz: 202 (1894); Dümmer: 201 (1913); Burtt Davy: 246 (1926); O.B.Mill.: 43 (1948); Brenan: 139 (1949). Type: South Africa, [Limpopo Province], Makapansberge, Rehmann 5470 (Z, holo. e!).

C. sambesiacum Engl. \& Diels: 63 (1899). Type: Mozambique, Boroma, Menyhárth $892 b$ (B, holo. †; Z, lecto. e!, designated here; K, fragment e!, WU, fragment e!, isolecto.).

C. hereroense Schinz subsp, hereroense var, villosissimum Engl. \& Diels: 63 (1899); Dümmer: 201 (1913); Wickens: 41 (1973). C. villosissimum (Engl. \& Diels) Engl.: 705 (1921). C. transvaalense Schinz var. villosissimum (Engl. \& Diels) Burtt Davy: 246 (1926). Type: South Africa, [Limpopo Province], Makapansberge, Streydpoort, Rehmann 5471 (Z, holo. e!).
C. porphyrolepis Engl. \& Diels: 63 (1899), nom. illegit.

C. rautanenii Engl. \& Diels: 64 (1899); O.B.Mill.: 43 (1948). Type: [Namibia], Katumare, Rautanen 199 (B, syn. †; Z, lecto. e!, designated here)

C. rhodesicum Baker f.: 435 (1899); Eyles: 428 (1916); O.B.Mill.: 43 (1948). Type: [Zimbabwe], Bulawayo, Rand 582 (BM, syn.) and Rand 583 (BM, syn.).

C. transvaalense Schinz var. bolusii Dümmer: 201 (1913). Type: South Africa, [Mpumalanga], Juxta ripas flum. Kaup prope Barberton', Bolus 7763 (K, holo. e!)

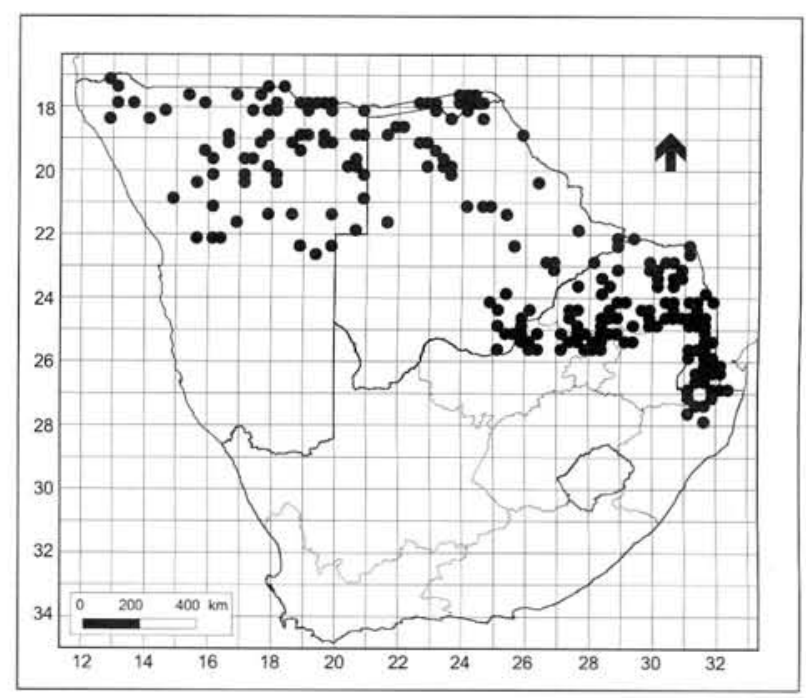

FIGURE 18.- Known distribution in FSA region of Combretum hereroense.

Note: Menyhárth $892 b$, collected in Mozambique, is the type of Combretum sambesiacum (Engler \& Diels 1899). The only acceptable extant specimen is housed in the Zürich Herbarium which is chosen as the lectotype. Specimens in $\mathrm{K}$ and WU are merely fragments. Engler \& Diels (1899) mentioned Rautanen 199 and three specimens of Fleck in their protologue of Combretum rautanenii. None of the Fleck specimens are available on the Zürich Herbarium website, only Rautanen 199, after which the species was named.

Distribution: Angola, Botswana, Kenya, Malawi, Mozambique, Namibia; RSA: Gauteng, KwaZulu-Natal, Limpopo Province, Mpumalanga, North-West; Swaziland, Tanzania, Uganda, Zambia, Zimbabwe (Figure 18).

IX. Combretum sect. Campestria Engl. \& Diels (= sect. Elaeagnoidea Engl. \& Diels) (Stace 1981)

Exell (1978) placed C. elaeagnoides Klotzsch in sect. Elaeagnoidea Engl. \& Diels, but Stace (1981) sank it under sect. Campestria, stating that there are four species in Africa belonging to this section. Of these, $C$. elaeagnoides is the only species south of the Zambezi River where it is restricted to the Flora zambesiaca region (including the Caprivi Strip in Namibia). It has a peculiar type of scales and the leaves, flowers and fruit are densely silvery lepidote. The flowers are 4-merous, arranged in dense, often subcapitate axillary spikes; the disc is without a free margin. C. elaeagnoides grows in the Zambezi Valley often forming dense thickets and is known in Zimbabwe as jesse-bush. 
24. Combretum elaeagnoides Klotzsch in Peters, Naturwissenschaftliche Reise nach Mossambique, Botanik 6, 1: 73 (1861); Engl.: 290 (1895); O.B.Mill.: 42 (1948); Exell: 7 (1968); Exell: 140 (1978); J.D.Carr: 63 (1988); A.E.van Wyk \& P.van Wyk: 330 (1997); M.Coates Palgrave: 801 (2002); Curtis \& Mannheimer: 491 (2005). Type: Mozambique, Sambesi Jitsch, Tete, Peters s.n. (B, holo.†; $\mathrm{BM}, \mathrm{K}$, fragment e!, iso.).

C. prunifolium Engl. \& Diels: 28 (1899), pro parte. Type: Mozambique, Boroma, Menyhárth 893 (Z, holo. e!; WU, iso. e!).

C. stevensonii Exell: 171 (1939); O.B.Mill.: 44 (1948). Type: Zambia, Mazabuka, Oct. 1929, Stevenson 99 (BM, holo. e!; FHO, iso.).

Note: the type of Combretum prunifolium Engl. \& Diels, Menyhárth $893(\mathrm{Z})$, consists of three specimens, the two upper ones being $C$. elaeagnoides and the lower one C. hereroense (Exell 1978).

Distribution: Botswana, Mozambique, Namibia, Zambia, Zimbabwe (Figure 17).

X. Combretum sect. Plumbea Jordaan, A.E.van Wyk \& O.Maurin in Maurin et al. (2010)

This section is named Plumbea, derived from the Latin word plumbum which means lead, referring to the heartwood of Combretum imberbe which is extremely hard, heavy and durable; hence the common name leadwood.

Exell (1978) placed Combretum imberbe Wawra in sect. Hypocrateropsis but separated it from all the other species in this section by its very densely lepidote leaves with scales mostly contiguous. It has rather large scales, $120-300 \mu \mathrm{m}$ in diameter, roughly circular, cells very numerous and small, divided by radial and tangential walls. A molecular phylogenetic study (Maurin et al. 2010) shows that $C$. imberbe is more closely related to $C$. elaeagnoides and $C$. hereroense than to the other members of sect. Hypocrateropsis and is treated here in a section of its own. In young growth, the branches are decussate and short lateral shoots end in a spinescent tip. The fruit is very small, less than $18 \mathrm{~mm}$ long and densely covered with silvery scales.

25. Combretum imberbe Wawra in Sitzungsberichte der Mathem.-Naturw. Classe der Kaiserlichen Akademie der Wissenschaften in Wien 38: 556 (1860); Engl. \& Diels: 14 (1899); O.B.Mill.: 43 (1948); Exell \& Roessler: 9 (1966); Exell: 7 (1968); Exell \& J.G.Garcia: 52 (1970); Wickens: 18 (1973); Exell: 109 (1978); Vollesen: 53 (1980); J.D.Carr: 81 (1988); Pooley: 358 (1993); A.E.van Wyk \& P.van Wyk: 332 (1997); McCleland: 462 (2002); M.Coates Palgrave: 803 (2002); Curtis

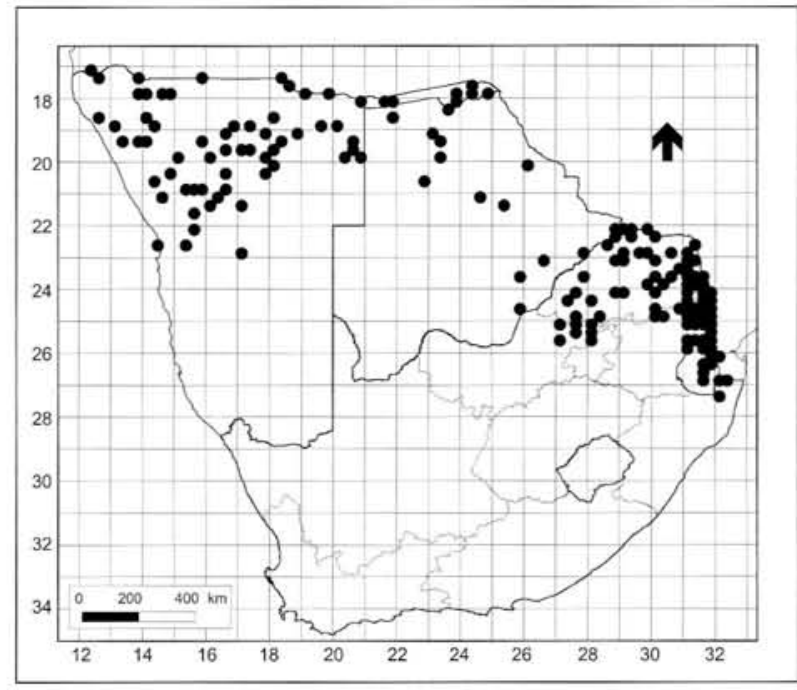

FIGURE 19.-Known distribution in FSA region of Combretum imberbe.

\& Mannheimer: 480 (2005). Type: Angola, Benguela, Wawra 247 (W e!, holo.; BM e!, iso.).

Argyrodendron petersii Klotzsch: 101 (1861). Combretum petersii (Klotzsch) Engl.: 290 (1895). C. imberbe Wawra var. petersii (Klotzsch) Engl. \& Diels: 14 (1899); Engl. \& Gilg: 314 (1903); Diels: 491 (1907). Type: Mozambique, Sena, Peters s.n. (B, holo.†). Mozambique, Zambezia entre Mocuba e Mugeba, a $36 \mathrm{~km}$ de Mocuba (Marata), Barbosa \& de Carvalho 2667 (WAG, neo. e!, designated here).

C. truncatum Welw, ex M.A.Lawson: 427 (1871); Dümmer: 231 (1913); O.B.Mill.: 44 (1948). C. imberbe Wawra var. truncatum (Welw. ex M.A.Lawson) Burtt Davy: 246 (1926). Type: Angola, Benguela, Catumbela, Welwitsch 4372 [LISU, lecto. e!, designated by Exell \& Garcia (1970); BM e!, K e!, isolecto.].

C. primigemum Marloth ex Engl.: 49 (1888); Engl. \& Diels: 14 (1899); O.B.Mill.: 43 (1948). South West Africa [Namibia], Hereroland, Usakos, Omumborombonga, Marloth 1264 (B, holo.†; GRA e!, $\mathrm{K}$ e!, $\mathrm{M}$ e!, PRE!, W e!, iso.).

Distribution: Angola, Botswana, Malawi, Mozambique, Namibia; RSA: Gauteng, KwaZulu-Natal, Limpopo Province, Mpumalanga, North-West; Swaziland, Tanzania, Zambia, Zimbabwe (Figure 19).

B. Combretum subgen. Cacoucia (Aubl.) Exell \& Stace (Exell \& Stace 1966 Wickens 1973)

\section{Cacoucia Aubl.: 450, t. 179 (1775).}

This subgenus is characterized by the absence of scales but the presence of microscopic (and sometimes macroscopic) stalked glandular hairs. The flowers are usually 5-merous (4-merous in sect. Conniventia).

Four sections are recognized.

\section{Key to sections of subgen. Cacoucia}

la Scrambling shrubs or woody climbers, with persistent petiole bases developing into curved spines; leaf lamina densely covered with translucent crystalliferous idioblasts; flowers orange to scarlet-red or white tinged pink; petals minutely hairy or pilose; fruit hairy or glabrous, with wings or wingless

sect. XI. Poivrea (p. 153)

Ib Scrambling shrubs, erect shrubs, climbers or suffrutices, without persistent petiole bases developing into curved spines; leaf lamina without crystalliferous idioblasts; flowers red, grey-green or white; petals glabrous or velvety; fruit sparsely hairy to velvety, always with wings:

2a Climbers, shrubs or suffrutices; flowers red; petals glabrous; fruit sparsely hairy on body only; Botswana, northern provinces of South

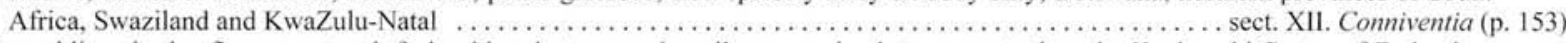

2b Scrambling shrubs; flowers not red; fruit with velvety covering all over; endemic to or centred on the Kaokoveld Centre of Endemism (Namibia and Angola):

3a Leaves opposite or in whorls of three, not longitudinally folded; flowers grey-green with a pinkish or reddish tinge 
XI. Combretum sect. Poivrea (Comm. ex DC.) G.Don (1832); Wickens: 57 (1973); Exell: 154 (1978)

Combretum mossambicense and $C$. bracteosum belong to this section. They are characterized by the lack of epidermal scales and the presence of gland-tipped hairs on the midrib and lateral veins, hairy pockets in the axils of veins below and translucent gland dots in the leaf lamina. Species in this section have relatively large and showy flowers, usually 5-merous and up to 10 $\mathrm{mm}$ long with protruding stamens. The fruit are usually 5 -winged or 5-angled. C. mossambicense has white or pinkish flowers and is one of the few species of Combretum in southern Africa with hairy fruit. The only other species of Combretum with pubescent or woolly fruit in our region belong to other sections, namely $C$. albo-punctatum, C. collinum subsp. suluense, $C$. hereroense, $C$. moggii, $C$. oxystachyum and $C$. wattii. Combretum bracteosum and $C$. mossambicense have petioles which persist as a recurved woody spine or hook. Similar recurved hooks are found in Quisqualis parviflora Sond. Combretum bracteosum is a free-standing, muchbranched, many-stemmed shrub, but may climb on other vegetation. It has scarlet or red flowers, but differs from all other southern African species of Combretum in having wingless fruit.

26. Combretum bracteosum (Hochst.) Brandis in Engl. \& Prantl, Die natürlichen Pflanzenfamilien 3,7: 125 (1893); Engl. \& Diels: 95 (1899); Dümmer: 68 (1913); Bews: 146 (1921); J.D.Carr: 37 (1988); Hennessy: t. 2028 (1991b); Pooley: 354 (1993); M.Coates Palgrave: 796 (2002). Type: South Africa, [KwaZuluNatal], 'in sylvis prope fl. Umlaas', Krauss 350 [B, holo †; BM000902273, lecto. e!, designated here; G e!, $\mathrm{MO}$, fragment e!, S, fragment e!, W, fragment e!, isolecto.].

Poivrea bracteosa Hochst.: 424 (1844); Sond.: 512 (1862); Sim: 223 (1907).

Codonocroton triphyllum E.Mey:: 149 (1843), nom. nud. Type: South Africa, [Eastern Cape], between Omtata [Umtata] and Omsamvubo [Umzimvubu] Rivers, Drège s.n. (S, holo. e!).

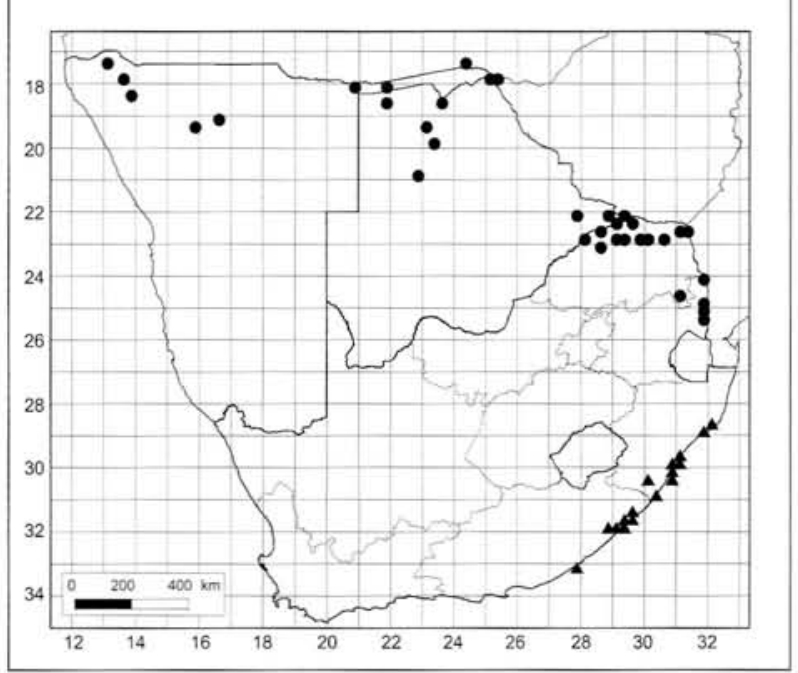

FIGURE 20.- Known distribution of Combretum mossambicense, and $C$. bracteosum, $\boldsymbol{A}$
Note: Krauss 350 in the British Museum (BM), type of Combretum bracteosum, is an acceptable flowering specimen chosen here as the lectotype; the isotypes in the other herbaria are merely fragments.

The name Codonocroton triphyllum does not seem to be validly published and only appeared in Meyer's, Zwei pflanzengeographische Documente von J.F. Drège (1843), collected by Drège in the Eastern Cape, a year before Hochstetter pulished the name Poivrea bracteosa, based on a specimen from KwaZulu-Natal. The Drège specimen at Stockholm Herbarium has a handwritten label and was mounted on the same sheet as S08-899, the type of Poivrea bracteosa, the name under which it is filed.

Distribution: RSA: Eastern Cape, KwaZulu-Natal (Figure 20).

27. Combretum mossambicense (Klotzsch) Engl., Die Pflanzenwelt Ost-Afrikas und der Nachbargebiete C: 292 (1895); Engl. \& Diels: 98 (1899); O.B.Mill.: 43 (1948); Stace: 14 (1961); Exell \& Roessler: 9 (1966); Exell: 6 (1968); Liben: 26 (1968); Exell: 219 (1970); Exell \& J.G.Garcia: 78 (1970); Wickens: 63 (1973); Exell: 156 (1978); A.E.van Wyk \& P.van Wyk: 334 (1997); M.Coates Palgrave: 807 (2002); Curtis \& Mannheimer: 482 (2005). Type: Mozambique, Manica e Sofala, Sena, Peters s.n. (B, holo.†; BM, fragment, K, fragment e!, iso.).

Poivrea mossambicensis Klotzsch: 78, t. 13 (1861).

C. ukambense Engl.: 291 (1895). Type: Kenya, Kitui in Ukamba, Hildebrandt 2779 (B, holo $\uparrow ; ~ K$, lecto. e!, designated here; M e!, P e!, W e!, isolecto.).

C. trichopetalum Engl.: 292 (1895); Engl. \& Diels: 97, t. 28, fig. C (1899). Tanzania, Mwanza Dist., Makolo, Stuhlmann 722 \& Bukumbi, Stuhlmann 822 \& without locality, Fischer 250 (all syn. at B †े).

C. guangense Engl. \& Diels: 98 (1899). Type: Angola, Cuanza Norte, Golungo Alto, Welwitsch 4282 [BM, lecto. e!, designated by Exell \& Garcia (1970); COI, G e!, K e!, LISU e!, P e!, isolecto.].

C. cataractarum Diels: 508 (1907); N.E.Br.: 111 (1909); Burtt Davy: 248 (1926); Eyles: 427 (1916); O.B.Mill.: 42 (1948). Type: Zimbabwe, Victoria Falls, Oct. 1904, Allen s.n. (B, syn. $\dagger$ ) and Ufer, country unknown, Sept. 1905, Engler 2925 (B, syn.†).

C. phillipsii Dümmer: 116 (1913). Type: South Africa, [Mpumalanga], Komatipoort, Kirk 57 (K, holo. e!).

C. detinens Dinter: 170 (1919). Type: [Namibia], between Franzfontein and Outjo, Dinter 2645 (SAM, iso. e!).

Note: the holotype of Combretum ukambense was destroyed and of the four extant isotypes, the one in Kew has the best preserved flowering material and is therefore chosen as the lectotype.

Distribution: Botswana, DRC, Kenya, Malawi, Mozambique, Namibia; RSA: Limpopo Province, Mpumalanga; Tanzania, Uganda, Zambia, Zimbabwe (Figure 20). (1899)

XII. Combretum sect. Conniventia Engl. \& Diels

This section falls under subgen. Cacoucia because scales are absent but the leaves have stalked glandular 
hairs. Flowers are red, 4-merous and the petals are glabrous. Ventenat (1808) described Combretum paniculatum from a plant collected in Senegal, West Africa and C. microphyllum was described by Klotzsch (1861) from a plant collected in Mozambique. Wickens (1971c, 1973 ) reduced $C$. microphyllum to a subspecies of $C$. paniculatum. Exell $(1968,1978)$ raised C. microphyllum to species level. Coates Palgrave (1977) placed $C$. microphyllum under $C$. paniculatum and therefore considers this as an aggregate species occurring in most parts of tropical and subtropical Africa. Exell (1978) and Carr (1988) consider C. paniculatum and C. microphyllum as two distinct species and there seems to be enough molecular evidence (Maurin et al. 2010) to maintain these two species. Chemotaxonomic studies conducted by Carr \& Rogers (1987), however, found identical extracts for these two species suggesting that they are closely related, but they unfortunately did not include C. platypetalum Welw. ex M.A.Lawson in their studies, a species from the Flora zambesiaca region and further north, which forms part of this complex (see below). $C$. paniculatum flowers usually in autumn (March-May) and the leaves remain on the plant when in flower. The leaves and flowers are larger than in C. microphyllum, a deciduous species that flowers usually in spring (September and October) when no leaves are visible on the plants. Exell (1978) pointed out that, although it is difficult to separate C. microphyllum and $C$. paniculatum in the herbarium, the two species are different in the field and they are also ecologically distinct. C. paniculatum occurs in forest and forest edges in the Soutpansberg region of South Africa. C. microphyllum grows on river banks of, for example, the Limpopo, Letaba, Olifants, Crocodile, Sabi, Komati, Ngwavuma, Pongola and Mkuze Rivers in South Africa in open lowveld savanna in full sun. It has become a popular garden plant in subtropical gardens. Flowers of both species are rich in nectar and are eagerly visited by nectar-feeding sunbirds and passerine birds. The flowers are also visited by honeybees.

Combretum platypetalum is a multi-stemmed, sparsely branched to virgate dwarf shrub (geoxylic suffrutex) up to $1.5 \mathrm{~m}$ high (subsp. oatesii does not exceed $500 \mathrm{~mm}$ ) with a thick woody rhizome, occurring in the Flora zambesiaca region as well as Namibia, Botswana, DRC, Angola and Tanzania. The differences between subsp. platypetalum and subsp. baumii (Engl. \& Gilg) Exell are not clear because both have hairy leaves and flowers, and we accept the view of Exell (1978) and Carr (1988) that only the typical subspecies occurs in northeastern Namibia crossing the border into Botswana. Subsp. oatesii (Rolfe) Exell differs from the other two subspecies by its glabrous leaves. Exell (1978) cites one specimen from Botswana, Rogers 6109 (SRGH), collected at Lobatsi, under C. platypetalum subsp. oatesii (Rolfe) Exell. No specimen of this taxon has been located in the National Herbarium, Pretoria (PRE) and it is doubtful whether subsp. oatesii actually occurs in southeastern Botswana. Further investigation is needed to confirm its presence in southern Africa.

28. Combretum microphyllum Klotzsch in Peters, Naturwissenschaftliche Reise nach Mossambique, Botanik 6,1: 74 (1861); Dümmer: 183 (1913); Burtt Davy: 246
(1926); I.Verd.: t. 978 (1945); O.B.Mill.: 43 (1948); Exell: 6 (1968); Exell: 150 (1978); Vollesen: 53 (1980); Pooley: 360 (1993); McClelan: 464 (2002); M.Coates Palgrave: 804 (2002). Type: Mozambique, Manica e Sofala, vicinity of Rios de Sena and Tete, Peters s.n. (B, holo.†; BM, fragment, lecto. e!, here designated).

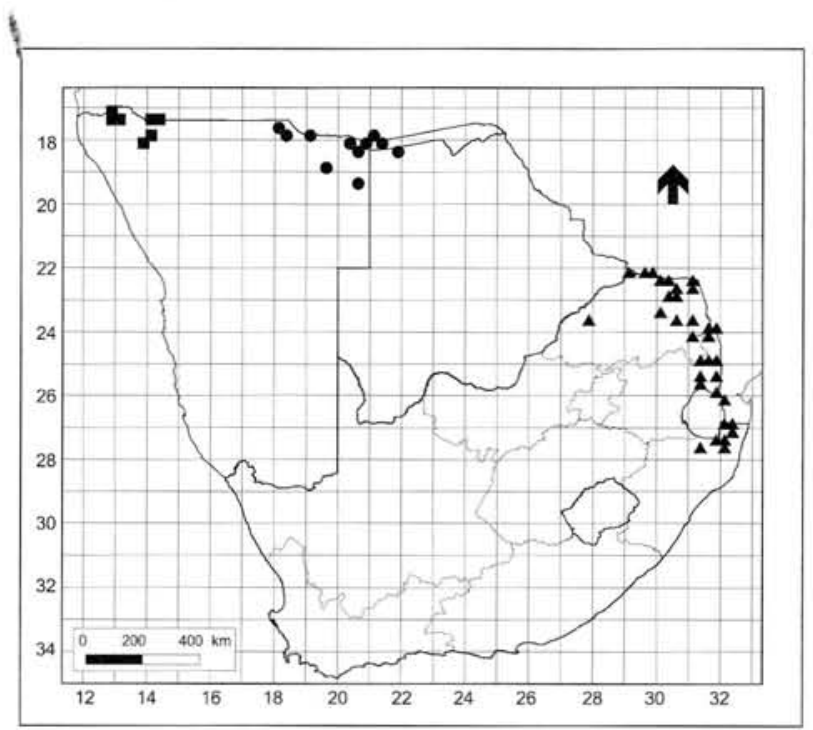

FIGURE 21.-Known distribution in FSA region of Combretum platypetalum subsp. platypetalum, $\mathbf{-}$. microphyllum, $\mathbf{\Delta}$; and $C$. oxystachyum,

C. paniculatum Vent. subsp. microphyllum (Klotzsch) Wickens: 66 (1971c); Wickens: 53 (1973).

C. lomuense Sim: 62, t. 61/B (1909). Type: Mozambique, without precise locality, Sim 6393 (not traced).

Note: the holotype of Combretum microphyllum was destroyed in Berlin and the only extant isotype is in BM, although merely a fragment.

Distribution: Botswana, Malawi, Mozambique; RSA: KwaZulu-Natal, Limpopo Province, Mpumalanga; Swaziland, Tanzania, Zambia, Zimbabwe (Figure 21).

29. Combretum paniculatum Vent., Choix de Plantes, sub. T. 58 (1808); G.Don: 424 (1827); M.A.Lawson: 425 (1871); Exell: 171 (1928); Exell: 175 (1944); F.W.Andrews: 203 (1950); F.White: 283 (1962); Liben: 34 (1968); Exell: 212 (1970); Exell \& J.G.Garcia: 69 (1970); Wickens: 52 (1973); Exell: 149 (1978); Vollesen: 53 (1980); Liben: 37 (1983); D.J.Carr: 120 (1988); Vollesen: 120 (1995); A.E.van Wyk \& P.van Wyk: 336 (1997); Jongkind: 70 (1999); M.Coates Palgrave: 809 (2002). Type: Senegal, Roussillon 60 in Herb. Jussieu 13632 (P-JU, holo.).

C. ramosissimum Engl. \& Diels: 72 (1899). Type: Sierra Leone, Afzelius s.n. (B, syn. $\dagger$ ); Bioko, Mann 203 (B, syn. $\dagger$; K, P, isosyn.); Gabon, Soyaux 86 (B, syn.†; K, iso.); Cameroun, Zenker 210 (B, syn.†); Cameroun, Zenker \& Staudt 177 [B, syn.†; K, lecto., designated by Jongkind (1999), BM, isolecto. e!].

Distribution: Angola, Benin, Bioko, Burkina Faso, Cameroon, Cote d'Ivoire, DRC, Ethiopia, Gambia, Guinea, Guinea-Bissau, Kenya, Liberia, Malawi, Mali, Mozambique, Nigeria; RSA: Limpopo Province; São Tomé, Senegal, Sierra Leone, Sudan, Tanzania, Uganda, Zimbabwe (Figure 22). 


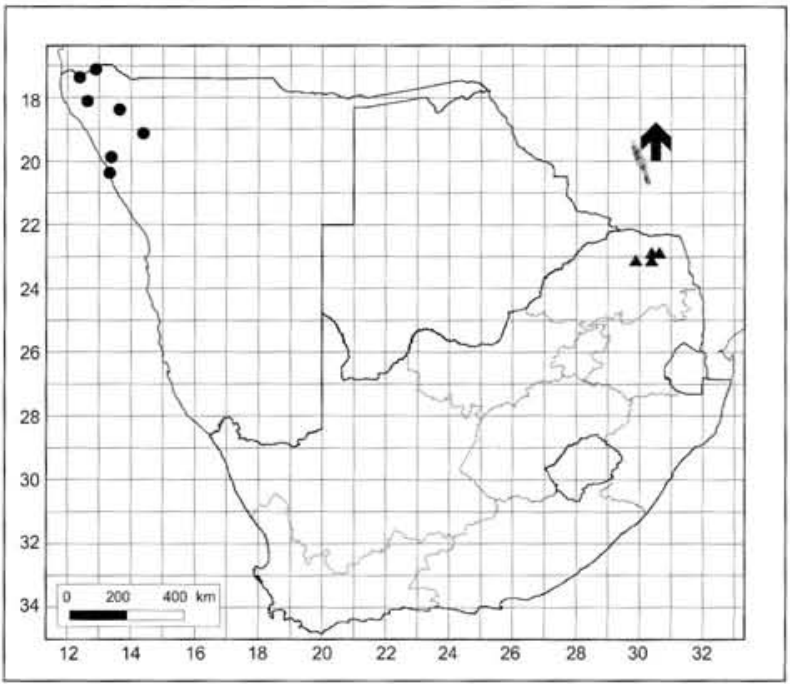

FIGURE 22,-Known distribution in FSA region of Combretum wattii, ; and C. paniculatum,

30. Combretum platypetalum Welw. ex M.A.Lawson subsp. platypetalum in Flora of tropical Africa 2: 433 (1871); Engl. \& Diels: 68 (1899); Exell: 7 (1968); Liben: 39 (1968); Exell: 214 (1970); Exell \& J.G.Garcia: 71 (1970); Wickens: 54 (1973); Exell: 151 (1978); Curtis \& Mannheimer: 493 (2005). Type: Angola, Huila, MumpulaHumpata, Welwitsch 4356 (LISU, holo.; BM e!, COI, K e!, P e!, iso.).

C. zastrowii Dinter: 174 (1919); O.B.Mill.: 44 (1948). Type: [Namibia], Grootfontein to Okavango, Zastrow in Herb. Dinter 3135 a (SAM, iso. e!).

Distribution: Angola, Botswana, DRC, Namibia, Zambia (Figure 21). $(1968)$

XIII. Combretum sect. Megalantherum Exell

Only one very distinct species, Combretum wattii Exell endemic to the Kaokoveld Centre of Endemism in northwestern Namibia and southwestern Angola (Van Wyk \& Smith 2001), belongs to this section. It has leaves in pairs or in whorls of three and the foliage is confined mainly to short lateral shoots emerging from older wood. A single flower terminates the lateral shoots, accompanied by further individual flowers in one or two sets of distal axils, up to five flowers per lateral shoot. The colour of the flowers is also unusual in being grey-green with a pinkish or reddish tinge. They have a nectariferous disc and are densely pubescent with dark brown stalked glands. The stamens and style are exserted beyond the petals, green at first, becoming reddish. The fruits are 5-winged.

31. Combretum wattii Exell in Mitteilungen der Botanischen Staatssammlung München 4: 5 (1961); Exell \& Roessler: 11 (1966); Exell \& J.G.Garcia: 79 (1970); A.E.van Wyk \& P.van Wyk: 336 (1997); M.Coates Palgrave: 812 (2002); Curtis \& Mannheimer: 486 (2005). Type: [Namibia], Kaoko-Otavi, 1939, Watt 1766 (M e!, holo.).

Distribution: Angola, Namibia (Figure 22).

\section{Combretum sect. Oxystachya Exell (1968)}

Only one species from the FSA region, C. oxystachyum Welw. ex M.A.Lawson from the Kaokoveld and adjacent parts of Namibia, belongs to this section. It is a scrambling shrub or climber and the leaves are longitudinally folded, with dense white hairs and stalked glands. The flowers are white with crimson to reddish brown stamens. The fruit is 5-winged.

32. Combretum oxystachyum Welw. ex M.A.Lawson in Flora of tropical Africa 2: 422 (1871); Hiern: 341 (1898); Exell \& Roessler: 10 (1966); Exell: 26 (1968); Exell \& J.G.Garcia: 77 (1970); Curtis \& Mannheimer: 492 (2005). Type: Angola, Bumbo, Quitibe de Cima, 1860, Welwitsch 4309 (LISU, holo.; BM, iso. e!).

Distribution: Angola, Namibia (Figure 21).

\section{SPECIMENS EXAMINED}

Specimens are held at PRE, unless otherwise indicated. The numbers in brackets are the species numbers as used in the text.

Abbott 82 (13). Acocks 9132 (1); 12985 (6). Archer 494 (27). Archibald 3959 (1).

Babich 9 (27). Balkwill \& Cadman 1418 (13). Banks 25 (27); 58 (12b). Barrett 12 (28). Bayliss 677 (1). Baytopp 156 (28) UNIN (fide Miller 1948, Setshogo \& Venter 2003); 275 (27). Biegel, Pope \& Gibbs Russell 4043 (27); 4049 (12b). Biggs 273 (11). Bodenstein 619 (18). Bokelmann s.n. (26). Boshoff \& Mason 257 (12b); 283 (9); 301 (22a). Boss TVM34971 (22b). D.J. Botha 340 l (20); 3522 (28). N.M. Botha FDH2889 (13). Botha \& Bredenkamp 3608 (22a). Botha \& Cilliers 3678 (27). Bowbrick BA625 (17d) SRGH. Bower 9148 (22a). Braun 153 (28), Breijer TRV16043 (28). Brown 7966 (9); 8713 (11). Brusse 6330 (22c). Brynard \& Adendorff 4504 (22d). Buitendag 862, 948 $(22 \mathrm{c}) ; 911$ (22a); 1237 (13). Burger 596 (14); 1260 (27). Burgoyne 3262 (9); 3358, 3417 (22a).

Carr 72 (22b); 73, 98 (22a); 79, 107 (11); 96, 115 (17a); 99 (9); 146 (12b); 192 (7). Cawood \& Ward 9 (22a). Codd 3025, 4334, 4364 (28); 4448,5726 (27); 6031, 10291 (6); 7079 (22a); 10326 (14). Codd \& Dyer 4585 (20). Coetzee 1195 (4); 1342 (22c). Cole 978 (27). Comins 1715 (1). Compton 26036, 28852, 32363 (22c); 30065 (6); 30145 (28). Cresswell 34 (22a). Culverwell 654, 955 (6); 709, 787 (22c). Curson 119 (10). Curtis 962a, 1022 (17b); 966 (22b); 996, 1081 (9); 1043 (22a).

Dehning RWD9413 (4). De Winter 3644, 3850, 9147 (22a); 3726, 3854 (17b); 3734, 4778 (9); 3861 (12b); 3923 (30); 5760 (31); 6008 (14); 9220, 9247 (24). De Winter \& Giess 6953 (9); 6954, 7000 (22b); 6961 (17a); 6999 (17b); 7106 (32). De Winter \& Leistner 5392, 5906 (32). De Winter \& Marais 4593 (27). De Winter \& Wiss 4204 (22a); 4267 (17a); 4286 (30). Du Plessis 279 (14). Du Preez \& Steenkamp 104 (22a). G.J. du Toit 5133 (27). P.C.V. du Toit 875 (28). Dyer 26 (1); $4349(6)$.

Edwards 1835, 4115 (6); 3139, 3147, 3330 (13); 4337, 4449 (18); 4339, 4395, 4405 (22a); 4398, 4416 (9); 4404, 4446 (17b). Erens 365 (24). Esterhuyse 441 (18).

Fourie 1332 (14). Foye 14 (28). Friederich FRI2/77 (17b); FR12/79 (22a).

Galpin 2977. 8116, 11554 (1); 13697, 13853 (28). Geldenhuys 328, 334 (9). Germishuizen 949 (14); 6107 (22c). Gerstner 5887 (22a). Gibbs Russell 4007 (1). Giess 8967, 12385, 14795 (12b); 9303, 9311, $9469,9478,9515,9790,10003,10142,10149,11473,12363,15108$ (22a); 9793 (9); 9881 (17a); 9891, 10139, 10146a, 12365, 14803 (17b); 10114 (30); $10500,10504,15463$ (27): 10505 (31); 14898 (11). Giess \& Leippert 7004 (22c); 7581 (18). Giess \& Loutit 14111 (27); 14166 (9). Giess \& Van der Walt 12635 (32). Giess, Volk \& Bleissner 6571 (12b). Gillett 3034 (28). Glen 1827 (22a); 3743 (14). Goosen 
41 (22a). Greemway \& Hoyle 8340 (17c). Greenway \& Kanuri 14299 (17d). Grobbelaar 66a (32). Gush 24 (28).

Hansen 3473 (27). Hardy 7122 (17b). Hardy \& Scott-Smith 1534 (6). Hardy \& Wells 376 (27). Heath 560 (14). Hemm 36 (14); $97 a$ (22c). Herman 856 (1). Hines 533 (18). Horler 209 (22c). Horn 167 (18). Hornby 2413,2611 (17d). Hutchinson 2522 (22c).

\section{Ihlenfeldt, De Winter \& Hardy 3215 (31).}

Jacobsen 3122 (18); 5043, 5142 (9); 5492 (14). Jacot Guillarmod 9471 (1). Jenkins TRV8145 (28). Joffe 1079 (22c). Jordaan 3068 (22c). Joubert PRF8721 (22c); PRF9513 (22d).

Karsten s.n. (22c). Kayombo 976, 977 (17d). Keet 1657 (30). Killick 3842 (22c). Killick \& Leistner 3204 (18); 3205 (22a); 3207 (17a). Kirkman 3089 (1). Klaassen \& Austaller EK169 (27). Koker 17 (29). Kolberg 746 (22a). Kolberg \& Loots HK965 (22b). Kolberg, Loots \& Moses HKIII25 (32); HKII66 (27). Kolberg \& Tholkes HK768 (31). Kreulen 493, 534, 538 (22a). I. Kruger s.n. (22a). P.R. Kruger 282 (13). Krynauw 1351 (21).

Lang TVM30169 (27); TRV30579, TRV30935 (28). Leistner, Oliver: Steenkamp \& Vorster 7 (32); 39 (22b); 70 (22a). Lemmer 13539 (17d). Le Roux 85, 151 (9); 166 (30); 1086 (22a). Letty 212 (26). Ley 154 (21). Liebenberg 4910 (9). Liengme 199 (28); 431 (22c). Lindstedt 86 (1). Loeb 144 (22c); 297 (9). Lötter 753 (19). Louw 2721 (6).

MacKenzie 30 (17b); 40 (9); 62 (22a). Maguire 1628, 2064 (30). Mannheimer \& Curtis CM709, CM726 (32). Mason \& Boshoff 301 (22a). Mauve 1055 (26); 5256 (6). McFerren 8a (17a). McKay 1978 (24). Meeuse 9701 (27). Merxmüller \& Giess 1392, 1555 (31); 1512 (32); 2002 (9); 2149 (17b); 30238 (12b); 30445 (22a). J.J. Meyer 4158 (28); BP00354 (22c). P.G. Meyer 1287 (32). Miller B/43, B/334 (27); B/106, $B / 1274$ (18); $B / 178$ (22a); $B / 181$ (11); $B / 424$ (30); B/641, B/1199 (9); $B / 1200$ (24); B/1318 (17a); B/1341 (22a); PRF5377 (26). Mills 397 (26). Milne-Redhead 405 (22b). Mogg 17300, 37502 (14); 37096 (22c); 37485 (4). Moll 813 (13); 2091 (6); 4359 (7); 5655 (20). Moll \& Muller 5688 (20). Moss PRE32234 (26). Miiller 321 (17b); 322 (22a); 1833 (27). Müller \& Biegel 2257 (17a); 2274 (11). Müller \& Giess 444 (17a); 502 (30); 585, 602 (9). Mullin 1/52 (17d) SRGH.

Nel 119 (22d); 180 (22a); 237 (6). Netshiungani 996 (22c). Nicholson 2122, 2250 (13). Nienaber EN223 (28).

Oates 33 (22c). Obermeyer 542 (22c); 978 (29); TVM36098 (22d). Onderstall 777 (28). Orpen 200, 971 (17d) SRGH.

Pegler 2076 (1). Pienaar 49 (22c); 139 (26); 435 (27). Pienaar \& Vahrmeijer 483 (9). Pole Evans 3236 (22b); 3702 (22a); 4598 (10). Porter 330, 342 (22c). Poynton 19428 (14).

P. Raal \& G. Raal 1332 (14). Repton 3861 (14); 6415 (27). E. Retief 247 (1). I.M. Retief 205 (28). Richards 10035, 19084 (17d) SRGH. Roberts I821A (1). Rodin 8978, 9310 (17b); 9119 (9); 9139 (22a). Rogers 2608 (27). Ross 1892 (13). Rossouw 248 (22a).

Scheepers 1133 (22a). Schoenfelder S53I (17b). Seely SEE/47 (22a). Silver SIL28 (22a). Smith 85 (17a); 173, 249, 1164, 1707, 1710, 2593, 2943 (11); 244, 314, 3434, 5686 (22a); 322, 2864 (9); 2063 (24); 2851 , 3433, 4051 (17a); 3874 (1). Smook 1335 (6). Smuts 56 (22a); 2078. 2277 (17d). Stalmans 1046 (22c); 1215 (14). Steel 463 (22d). Stephen 335 (28). Steyl 21 (17a); 60 (24); 67 (12b). Steyn 10 (4); 11 (22d); 13 (19); 15 (6); 16 (22a); 17 (21); 18 (22c); 23 (32); PRE61956 (14). Story 2120 (1); 3962 (28); 4651 (27); 4723, 5052, 5270, 5330 (22a); 5093, 6493 (9); 5870 (31); 6356 (12b); 6461 (17b); 6465 (30). Straub 438 (28); 633 (27). Strey 6422, 6850, 7320 , (26); 11148 (1). Strey \& Moll 3750 (28). Swelankomo 29 (4).

Taylor 2129 (13). G.C. Theron 1067 (1); 1569 (26). G.K. Theron 2604 (22a). Thorncroft TVM22210 (21). Tinley 1004 (7); 1075 (22a); 1425 (24); 1427 (18); 1478 (17a); $1496(11) ; 1501$ (30).

\section{Uiras MU622 (17b); MU652 (9). Uys 2/65 (17d) SRGH.}

Vahrmeijer \& Du Preez 2510 (18); 2626 (22c). Vahrmeijer \& Tölken 970 (28). Van Daalen $504 b$ (22a). Van der Merwe 58 (22a); 62 (19). Van der Schijff 61, 819 (28); 1010 (27); 1657 (6); 2151, 2898 (20); 3153, 3816, 3822 (22a); 5585 (13). Van der Walt 9510 (20). Van Graan \& Hardy 543 (27). Van Greuning 247 (22a). Van Jaarsveld 735
(28); 1164 (21). A.S. van Rensburg PRF11303 (26). J.H. van Rensburg 3034 (17d) SRGH. Van Rooyen \& Bredenkamp 609 (19). Van Son TVM28827 (22a); TVM28828 (24). Van Steenis 24011 (26). Van Warmelo 51 z 19/27 (29). A.E. van Wyk 2944 (14); 3069 (22c); 3215 (1); $5188 a$ (27); 6673 (5). A.E. van Wyk \& Theron 4913 (28). B.-E. van Wyk \& C.M. van Wyk 1423(g) (1). E. van Wyk evw0095 (22d); avwl12 (22a); evw 117 (14). E. van Wyk \& Gavhi evw300 (7); ewv353 (19). E. van Wyk, Nkuna \& Dlamini 557 (28). P. van Wyk BSA900 (22a); BSA905, BSA916 (17a); BSA918 (9); BSA940 (29); BSA1724 (18); BSA2029 (20); 4763 (19). F. Venter 7265, 7821 (22a); 10338 (4). H.J.T. Venter 6032 (26). Verhoeven 61 (19), Volk 238, 419 (17b). Von Breitenbach 19831 (22d); 20288 (4). Von Teichman 233 (22a).

Walsh 10842 (22a). C.J. Ward 526, 8614, 8727 (26); 2130 (6); 7276 (28); 8793 (7). M.C. Ward 1027 (28); 2286, 2301 (20). Ward \& Hines 10334 (30). Wells 1855 (6); 3515 (26); 3587 (1). Wentzel 14 (22c). Westfall 998 (14); 1578 (4). Westphal 16 (27). Wild \& Drummond 6840 (11); 6986 (9). Wirminghaus 1144 (13).

Yalala $416(11)$.

Zambatis 323 (27); 1225 (28).

\section{ACKNOWLEDGEMENTS}

We would like to thank Hester Steyn for the distribution maps, Daleen Roodt for the line drawings and Meg Coates Palgrave for checking certain specimens in the Harare Herbarium (SRGH).

\section{REFERENCES}

ANDREWS, F.W. 1950. The flowering plants of the Anglo-Egyptian Sudan 1. Buncle, Scotland.

AUBLET, J.B.C.F. 1775. Histoire des plantes de la Guiane française 1. Londres, Paris

BAKER, E.G. 1899. Rhodesian Polypetalae. Journal of Botany 37: $422-438$.

BAKER, E.G. 1905. Mr. Eyles's Rhodesian plants. Journal of Botany 43: $44-54$

BEWS, J.W. 1921. Combretaceae. An introduction to the flora of Natal and Zululand. City Printing Works, Pietermaritzburg.

BRANDIS, D. 1898. Combretaceae. In A. Engler \& K. Prantl, Die natïrlichen Pflanzenfamilien III, 7: 106-130. Engelmann, Leipzig.

BREDENKAMP, C.L. 2000. Combretaceae. In O.A. Leistner, Seed plants of southern Africa: families and genera. Strelitzia 10:228, 229. National Botanical Institute, Pretoria.

BRENAN, J.P.M. 1949. Combretaceae. In J.P.M. Brenan \& P.J. Greenway, Check-lists of the forest trees and shrubs of the British Empire 5, part 2: Tanganyika Territory: 132-146. Imperial Forestry Institute, Oxford.

BROWN, N.E. 1909. List of plants collected in Ngamiland and the northern part of the Kalahari Desert, chiefly in the neighbourhood of Kwebe and along the Botletle and Lake Rivers. Kew Bulletin 1909: 89-146.

BURCHELL, W.J. 1822. Travels in the interior of southern Africa 1. Longmans, London.

BURTT DAVY, J. 1921. New or noteworthy South African plants. Kew Bulletin 1921: 278-288.

BURTT DAVY, J. 1926. A mamual of the flowering plants and ferns of the Transvaal with Swaziland 1. Longmans \& Green, London.

CARR, J.D. 1988. Combretaceae in southern Africa. Tree Society of southern Africa, Johannesburg.

CARR, J.D. \& RETIEF, E. 1989. A new species of Combretum from Natal. Bothalia 19: 38-40.

CARR, J.D. \& ROGERS, C.B. 1987. Chemosystematic studies of the genus Combretum (Combretaceae) I. A convenient method of identifying species of this genus by a comparison of the polar constituents extracted from leaf material. South African Journal of Botany 53: 173-176.

CLARKSON, J.R. \& HYLAND, B.P.M. 1986. Combretum trifoliatum Vent. (Combretaceae), a new record for Australia. Austrobaileya 2: $274-276$.

COATES PALGRAVE, K. 1977. Trees of southern Africa, edn 1. Struik, Cape Town. 
COATES PALGRAVE, M. 2002. Keith Coates Palgrave Trees of southern Africa, edn 3. Struik, Cape Town.

CODD, L.E.W. 1951. Trees and shrubs of the Kruger National Park. Memoirs of the Botanical Survey of South Africa No. 26: 128133. Government Printer, Pretoria.

CODD, L.E.W. 1956. Combretum zeyheri. The Flowering Plants of Africa 31: t. 1230.

COMPTON, R.H. 1976. The Flora of Swaziland. Journal of South African Botany, Suppl. vol. 11.

CURTIS, B.A. \& MANNHEIMER, C.A. 2005. Tree atlas of Namibia. National Botanical Research Institute, Windhoek.

DAHLGREN, R. \& THORNE, R.F. 1984. The order Myrtales: circumscription, variation and relationships. Annals of the Missouri Botanical Garden 71: 633-699.

DE CANDOLLE, A.P. 1828. Combretaceae. Prodromus systematis naturalis regni vegetabilis 3: 9-24. Treuttel \& Würtz, Paris.

DE WILDEMAN, E.A.J. 1914. Decades novarum specierum florae katangensis. Feddes Repertorium 13: 193-212.

DE WILDEMAN, Ė.A.J. 1921. Contribution à l'étude de la flore du Katanga. Reynaert, Bruxelles.

DIELS, F.L.E. 1907. Combretaceae africanae. Botanische Jahrbïcher 39: 485-515.

DINTER, K. 1919. Index, der aus Deutsch-Südwestafrika bis zum Jahre 1917 bekannt gewordenen Pflanzenarten IV. Feddes Repertorium 16: 167-174.

DON, G. 1827. A review of the genus Combretum. Transactions of the Linnean Society of London 15: 412-441.

DON, G. 1832. Combretaceae. A general system of gardening and botany 2: 655-667. Rivington, London.

DRĖGE, J.F. 1843. Zwei pflanzengeographische Dokumente. Leipzig.

DÜMMER, R.A. 1913. The South African Combretaceae. The Gardeners'Chronicle, ser. 3, 53: 52, 53, 67, 68, 116, 117, 147, 148, 164 , $165,181-183,201$.

DUVIGNEAUD, P. 1956. Géographie des caractères et évolution de la Flore Soudano-Zambézienne III: les Combretum arborescents des savanes et forêts claires du Congo Méridional. Bulletin de la Societe Royale de Botanique de Belgique 88: 59-90.

ECKLON, C.F. \& ZEYHER, K.L.P. 1834, 1835. Enumeratio plantarum africae australis extratropicae 1. Perthes \& Besser, Hamburg.

ENGLER, A. 1888. Plantae Marlothianae. Ein Beiträg zur Kenntnis der Flora Südafrikas 1. Monokotyledonae und Dikotyledonae archichlamydeae. Botanische Jahrbücher 10: 1-50.

ENGLER, A. 1895. Combretaceae. Die Pflanzenwelt Ost-Afrikas und der Nachbargebiete C: 288-295. Reimer, Berlin.

ENGLER, A. 1921. Combretaceae. Die Pflanzenwelt Afrikas 3, 2: 681729. Engelmann, Leipzig.

ENGLER, A. \& DIELS, F.L.E. 1899. In A. Engler, Monographien afrikanischer Pflanzen-Familien und -Gattungen 3: CombretaceaeCombretum. Engelmann, Leipzig.

ENGLER, A. \& DIELS, F.L.E. 1907. Combretaceae africanae. Botanische Jahrbücher 39: 487-515.

ENGLER, A. \& GILG, E. 1903. Combretaceae. In O. Warburg, KuneneSambesi-Expedition by H. Baum: 314-322. Kolonial-Wissenschaftliches Komitee, Berlin.

ENGLER, A. \& various authors. 1902. Plantae benguellense Antunesianae et Dekindtianae. A botanicis Musei Regii Berolinensis. Botanische Jahrbiicher 32: 128-152.

EXELL, A.W. 1928, Gossweiler's Portuguese West African plants. Combretaceae. Journal of Botany 66, Supplement Polypetalae: $164-174$.

EXELL, A.W. 1930. Notes from the British Museum Herbarium. Journal of Botany $68: 244-246$.

EXELL, A.W. 1939. Some new species of Dombeya, Grewia, and Combretum from tropical Africa. Journal of Botany, London 77: 165-173.

EXELL, A.W. 1944. Catalogue of the vascular plants of São Tomé. British Museum, London.

EXELL, A.W. 1961. New species and subspecies of Combretum from southern tropical Africa. Mitteilungen der Botanischen Staatssammlung München 4: 3-7.

EXELL, A.W. 1968. Notes on the Combretaceae of southern Africa. Boletim da Sociedade Broteriana, sér. 2, 42: 5-33.

EXELL, A.W. 1970. Summary of the Combretaceae of Flora zambesiaca. Kirkia 7: 159-252.

EXELL, A.W. 1978. Combretum. In E. Launert, Flora zambesiaca 4: 101-160. Flora zambesiaca Managing Committee, Glasgow.

EXELL, A.W. \& GARCIA, J.G. 1970. Combretaceae. Conspectus florae angolensis 4: 44-93. Junta de Investigações Cientificas do Ultramar, Lisbon.
EXELL, A.W. \& ROESSLER, H. 1966. Combretaceae. In H. Merxmüller, Prodromus einer Flora von Sïdwestafrika 99: 1-11. Cramer, Lehre.

EXELL, A.W. \& STACE, C.A. 1966. Revision of the Combretaceae. Boletim da Sociedade Broteriana, sér. 2, 40: 5-25.

EXELL, A.W. \& STACE, C.A. 1972. Patterns of distribution in the Combretaceae. In D.H. Valentine, Taxonomy, phytogeography and evolution: 307-323. Academic Press, London and New York.

EYLES, F. 1916. A record of plants collected in southern Rhodesia. Transactions of the Royal Society of South Africa 5: 273-564.

GUILlEMIN, J.B.A. \& PERROTTET, G. 1833. Combretum L. Florae Senegambiae Tentamen 3, 8: 284-290. Paris.

HENNESSY, E.F. 199 la. Combretum moggii. The Flowering Plants of Africa 51: t. 2027.

HENNESSY, E.F. 1991b. Combretum bracteosum. The Flowering Plants of Africa 51 : t. 2028.

HENNESSY, E.F. \& RODMAN, S. 1995. A note on Combretum subgenus Combretum section Macrostigmatea (Combretaceae). Bothalia 25: 149-153.

HIERN, W.P. 1898. Catalogue of the African plants collected by Dr: Friedrich Welwitsch, vol. 1. Trustees of British Museum, London.

HOCHSTETTER, C.F.F. 1844. Pflanzen des Cap- und Natal-Landes, gesammelt und zusammengestellt. Flora 27: 424.

HOFFMANN, F. 1889. Beiträge zu Kenntnis der Flora von CentralOst-Afrika. Loewenthal, Berlin.

HOLMGREN, P.K., HOLMGREN, N.H. \& BARNETT, L.C. 1990. Index herbariorum, part 1: The herbaria of the world, edn 8 . New York Botanical Garden, New York.

HOOKER, W.J. 1843. Combretum salicifolium. Hooker's Icones Plantarum, ser, 2, 6: t. 592.

JONGKIND, C.C.H. 1999. Combretaceae. In P. Morat, Flore du Gabon 35: 5-115. Muséum National d'Histoire Naturelle, Paris.

JORDAAN, M. 2003. Combretaceae. In G. Germishuizen \& N.L. Meyer, Plants of southern Africa: an annotated checklist. Strelitzia 14:369-371. National Botanical Institute, Pretoria.

JORDAAN, M. 2006. Combretaceae. In G. Germishuizen, N.L. Meyer, Y. Steenkamp \& M. Keith, A checklist of South African plants. Southern African Botanical Diversity Network Report No. 41: 329, 330. SABONET, Pretoria.

KLOPPER, R.R., CATELAIN, C., BÄNNINGER, V., HABASHI, C., STEYN, H.M., DE WET, B.C., ARNOLD, T.H., GAUTIER, L., SMITH, G.F. \& SPICHIGER, R. 2006. Checklist of the flowering plants of sub-Saharan Africa. South African Botanical Diversity Network Report No. 42. SABONET, Pretoria.

KLOTZSCH, J.F. 1861. Combretum elaeagnoides. In W.C.H. Peters, Naturwissenschaftliche Reise nach Mossambique, Botanik 6,1. Reimer, Berlin.

KUNTZE, C.E.O. 1898. Combretaceae. Revisio generum plantarum 3, 2: 87, 88. Felix, Leipzig.

LAWSON, M.A. 1871. Combretaceae. In D. Oliver, Flora of tropical Africa 2: 413-436. Reeve, London.

LIBEN, L. 1968. Spermatophytes. Combretaceae. Flore du Congo du Rwanda et du Burundi. Jardin Botanique National de Belgique, Bruxelles.

LIBEN, L. 1983. Combretum. In B. Satabié, Flore du Cameroun 25: 13-61. Délégation Générale à la Recherche Scientifique et Technique, Yaoundé.

LOFFLER, L. \& LOFFLER, P. 2005. Swaziland Tree Atlas, including selected shrubs and climbers. Combretaceae. Southern African Botanical Diversity Network Report No. 35: 62-65. SABONET, Pretoria.

MAURIN, O., CHASE, M.W., JORDAAN, M. \& VAN DER BANK, M. 2010. Phylogenetic relationships of Combretaceae inferred from nuclear and plastid DNA sequence data: implications for generic classification. Botanical Journal of the Linnean Society 162: $453-476$.

McClelAND, W. 2002. Combretaceae. In E. Schmidt, M. Lötter \& W. McCleland, Trees and shrubs of Mpumalanga and Kruger National Park: 456-474. Jacana, Johannesburg.

MCNEILL, J., BARRIE, F.R., BURDET, H.M., DEMOULIN, V., HAWKSWORTH, D.L., MARHOLD, K., NICOLSON, D.H., PRADO, J., SILVA, P.C., SKOG, J.E., WIERSEMA, J.H. \& TURLAND, N.J. (eds). 2006. International Code of Botanical Nomenclature (Vienna Code) adopted by the Seventeeth International Botanical Congress Vienna, Austria, July 2005. A.R.G. Gantner Verlag, Ruggell, Liechtenstein. Regmum Vegetabile 146. 
MEYER, E.H.F. 1843. Beigabe zur Flora. Zwei pflanzengeographische Documente von J.F. Drège. Leipzig.

MILLER, O.B. 1948. Combretaceae. Checklists of the forest trees and shrubs of the British Empire No. 6:42-44. Bechuanaland Protectorate. Scrivener Press, Oxford.

MOORE, S. 1921. Alabastra Diversa-Part XXXIV. Plantae Rogersianae-VI. The Journal of Botany 1921: 227.

OKAFOR, J.C. 1967. A taxonomic study of the Combretum collinum group of species. II. The subspecies of Combretum collinum. Boletim da Sociedade Broteriana, sér. 2, 41: 137-150.

PEDLEY, L. 1990. Combretaceae. Flora of Australia 18: 255-293. Australian Government Publishing Service, Canberra.

POOLEY, E.S. 1993. The complete field guide to trees of Natal. Zululand and Transkei. Natal Flora Publications Trust, Durban.

PRESL, K.B. 1844. Botanische Bemerkungen. Haase, Prague.

RENDLE, A.B. 1932. African notes II. Journal of Botany 70: 89-96.

RETIEF, E. 1986. A new species of Combretum from the Transvaal. Bothalia 16: 44,45 .

RICHARD, A. 1848. Tentamen florae abyssinicae 1. Bertrand, Paris.

RODMAN, S. 1990. The validity of currently recognized sectional limits within Combretum Loefling, subgenus Combretum (Combretaceae) in southern Africa. M.Sc. thesis, Department of Botany in the Faculty of Science at the University of Durban-Westville, Durban.

ROGERS, C.B. 1989. New mono- and bi-desmosidic triterpenoids isolated from Combretum padoides leaves. Journal of Natural Products 52: 528-533.

SCHINZ, H. 1888. Beiträge zur Kenntnis der Flora von Deutsch-Südwest-Afrika und der angrenzenden Gebiete. Verhandlungen des Botanischen Vereins der Provinz Brandenburg 30: 245-247.

SCHINZ, H. 1894. Beiträge zur Kenntnis der afrikanischen Flora. Combretaceae. Bulletin de l'Herbier Boissier 2: 202, 203.

SCHINZ, H. 1901. Beiträge zur Kenntnis der afrikanischen Flora. Combretaceae. Bulletin de l'Herbier Boissier, sér. 2, 1: 877-879.

SETSHOGO, M.P. \& VENTER, F. 2003. Trees of Botswana: names and distribution. South African Botanical Diversity Network Report No. 18. SABONET, Pretoria.

SIM, T.R. 1907. The forests and forest flora of the Colony of the Cape of Good Hope. Taylor \& Henderson, Aberdeen.

SIM, T.R. 1909. Forest flora and forest resources of Portuguese East Africa. Taylor \& Henderson, Aberdeen.

SONDER, O.W. 1850. Beiträge zur Flora von Südafrica. Combretaceae. Linnaea 23: 42-47.

SONDER, O.W. 1862. Combretaceae. In W.H. Harvey \& O.W. Sonder. Flora capensis 2: 507-513. Hodges \& Smith, Dublin.

STACE, C.A. 1961. Cuticular characters as an aid to the taxonomy of the South West African species of Combretum. Mitteilungen der Botanischen Staatssammlung München 4: 9-19.

STACE, C.A. 1965. The significance of the leaf epidermis in the taxonomy of the Combretaceae. I. A general review of tribal, generic and specific characters. Botanical Journal of the Linnean Society 59: $229-252$.

STACE, C.A. 1969. The significance of the leaf epidermis in the taxonomy of the Combretaceae. II. The genus Combretum subgenus Combretum in Africa. Botanical Journal of the Linnean Society 62: $131-168$.

STACE, C.A. 1980. The significance of the leaf epidermis in the taxonomy of the Combretaceae V. The genus Combretum subgenus Cacousia in A frica. Botanical Journal of the Linnean Society 81 : 185-203.

STACE, C.A. 1981. The significance of the leaf epidermis in the taxonomy of the Combretaceae: conclusions. Botanical Journal of the Linnean Society 81: 327-339.

STACE, C.A. 2007. Combretaceae. In K. Kubitzki, The families and genera of vascular plants 9: 67-82. Spinger Verlag. Berlin.

STAFLEU, F.A. \& COWAN, R.S. 1976-1988. Taxonomic literature, vol. 1-7. Bohn, Scheltema \& Holkema, Utrecht.

SUESSENGUTH, K. 1953. Neue Taxa, Kombinationen und Vorkommen in Süd-Afrika. Mitteilungen der Botanischen Staatssammlung München 1: 333-345.

SWYNNERTON, C.F.M. \& BAKER, J.G. 1911. Contribution to the flora of Gazaland. Dicotyledons, Polypetalae. Journal of the Linnean Society 40: 16-76.

SYTSMA, K.J., LITT, A., ZJHRA, M.L., PIRES, C., NEPOKROEFF, M., CONTI, E., WALKER, J. \& WILSON, P.G. 2004. Clades, clocks, and continents: historical and biogeographical analysis of Myrtaceae, Vochysiaceae, and relatives in the southern hemisphere. International Journal of Plant Science 165 (4 Suppl.): S85-S105.
THULIN, M. 1993. Combretaceae. Flora of Somalia 1: 247-254. Royal Botanic Gardens, Kew.

TILNEY, P.M. 2002. A contribution to the leaf and young stem anatomy of the Combretaceae. Botanical Journal of the Linnean Society 138: $163-196$

VAN HEURCK, H.F. \& MÜLLER.ARGOVIENSIS, J. 1871. Observationes botanicae et descriptiones plantarum herbaria Van Heurckiani. Antwerpen, Berlin.

VAN WYK, A.E. 1984. A new species of Combretum from Venda and taxonomic notes on the section Angustimarginata (Combretaceae). South African Journal of Botany 3: 125-134

VAN WYK, A.E. \& SMITH, G.F. 2001. Regions of floristic endemism in southern Africa. A review with emphasis on succulents. Umdaus Press, Pretoria.

VAN WYK, A.E. (Braam) \& VAN WYK, P. 1997. Field guide to trees of southern Africa. Struik Publishers, Cape Town.

VENTENAT, E.P. 1808. Choix de Plantes. Crapelet, Paris.

VERDOORN, I. 1945. Combretum microphyllum. The Flowering Plants of Africa 25: t. 978

VERHOEVEN, R.L. \& VAN DER SCHIJFF, H.P. 1973. A key to the South African Combretaceae based on anatomical characteristics of the leaf. Phytomorphology 23: 65-75.

VERHOEVEN, R.L. \& VAN DER SCHIJFF, H.P. 1975. A short note on Combretum edwardsii Exell. Journal of South African Botany 41: 39,40 .

VOLLESEN, K. 1980. Annotated check-list of the vascular plants of the Selous Game Reserve, Tanzania. Opera Botanica 59: 3-117.

VOLLESEN, K. 1986. Name changes for two well-known African Combretaceae. Kew Bulletin 41: 962.

VOLLESEN, K. 1995. Combretaceae. In S. Edwards, M. Tadesse \& I. Hedberg, Flora of Ethiopia and Eritrea 2, 2: 115-131. The National Herbarium, Addis Ababa University, Ethiopia.

WAWRA, H. 1860. Sertum Benguelense. Polypetalae. Sitzungsberichte der Mathem.-Naturw. Classe der Kaiserlichen Akademie der Wissenschafien in Wien 38: 556.

WELWITSCH, F.M.J. 1856. Parte não official. Annaes Conselho Ultramarino, sér. 1, 24: 249,250

WHITE, F. 1962. Forest flora of Northern Rhodesia. Oxford University Press, London.

WICKENS, G.E. 1971a. The Combretum hereroense complex (Combretaceae). Kew Bulletin 25: 411-416.

WICKENS, G.E. 1971b. The Combretum psidioides Welw. complex (Combretaceae). Kew Bulletin 26: 37-40.

WICKENS, G.E. 1971 c. Linear discriminant functions and the Combretum paniculatum Vent. and C. microphyllum Klotzsch complex in the Combretaceae. Kew Bulletin 26: 61-66.

WICKENS, G.E. 1973. Combretum. In R.M. Polhill, Flora of tropical East Africa, Combretaceae: 2-66. Crown Agents for Oversea Governments and Administrations, London.

WOOD, J.M. 1908. Revised list of the flora of Natal. Transactions of the South African Philosophical Society 18: 121-271.

Websites:

ALUKA LIBRARY. http://www.aluka.org [accessed March 2009].

ANGIOSPERM PHYLOGENY WEBSITE (APweb). 2008. www.mobot.org/MOBOT/Research/APweb/ [accessed August 2009].

ZÜRICH HERBARIUM http:/www.zuerich-herbarien.unizh.ch [accessed August 2008].

\section{INDEX}

Angustimarginata Engl. \& Diels, sect., 137

Argyrodendron petersii Klotzsch, 152

Breviramea Engl. \& Diels, sect., 151

Cacoucia (Aubl.) Exell \& Stace, subgen., 152

Cacoucia Aubl., 152

Campestria Engl. \& Diels, sect., 151

Ciliatipetala Engl. \& Diels, sect., 143

Codonocroton triphyllum E.Mey., 153

Combretum, subgen., 137

Combretum Loeff.

adenogonium Steud. ex A.Rich., 143

albopunctatum Suess., 145

angustilanceolatum Engl., 150

antunesii Engl. \& Diels, 142

apiculatum Sond.

subsp, apiculatum, 145

subsp. leutweinii (Schinz) Exell, 145 
var. parvifolium Baker f., 145 arengense Sim, 146 bajonense Sim, 149 bracteosum (Hochst.) Brandis, 153 buchananii Engl. \& Diels, 145 burttii Exell, 150 caffrum (Eckl. \& Zeyh.) Kuntze, 139

calocarpum Gilg ex Dinter, 142 cataractarum Diels, 153

celastroides Welw. ex M.A.Lawson, 148 subsp. orientale Exell, 148

chlorocarpum Exell, 142

collinum Fresen.

subsp. gazense (Swynn. \& Baker f.) Okafor, 149 subsp. ondongense (Engl. \& Diels) Okafor, 149 subsp. suluense (Engl. \& Diels) Okafor, 150 subsp. taborense (Engl.) Okafor, 150

coriaceum Schinz, 149

dekindtiamum Engl., 146

detinens Dinter, 153

dinteri Schinz, 147

dregeanum C.Presl, 139

edwardsii Exell, 145

eilkeranum Schinz, 151

elaeagnoides Klotzsch, 152

ellipticum Sim, 146

engleri Schinz, 142

erythrophyllum (Burch.) Sond., 139

var. obscurum Van Heurck \& Müll.Arg., 140

eylesii Exell, 149

ferrugineum A.Rich., 146

fragrans F.Hoffm., 143

galpinii Engl. \& Diels, 146

gazense Swynn. \& Baker f., 149

ghasalense Engl. \& Diels, 143

glomeruliflorum Sond., 139

var. obscurum (Van Heurck \& Müll.Arg.) Burtt Davy, 140

var. riparium (Sond.) Burtt Davy, 139

glutinosum sensu Wood, 145

goetzenianum Diels, 150

grandifolium F.Hoffm., 147

griseiflorum S.Moore, 150

guangense Engl. \& Diels, 153

gueinzii Sond., 146

subsp. splendens (Engl.) Exell ex Brenan, 146

var. holosericeum (Sond.) Exell ex Rendle, 146

hereroense Schinz

subsp. hereroense, 151

var. villosissimum Engl. \& Diels, 151

holosericeum Sond., 146

homblei De Wild., 148

imberbe Wawra, 152

var. petersii (Klotzsch) Engl. \& Diels, 152

var. truncatum (Welw. ex M.A.Lawson) Burtt Davy, 152 junodii Dümmer, 150

kraussii Hochst., 140

kwebense N.E.Br., 145

leutweinii Schinz, 145

lomuense $\mathrm{Sim}, 154$

lopolense Engl. \& Diels, 142

lucidum E.Mey. ex Drège, 140

lydenburgiamum Engl. \& Diels, 140

makindense Gilg ex Engl., 150

mechowianum $\mathrm{O}$.Hoffm.

subsp. gazense (Swynn. \& Baker f.) Duvign., 149

subsp. taborense (Engl.) Duvign., 150

microphyllum Klotzsch, 154

millerianum Burtt Davy, 150

minutiflorum Exell, 148

mkuzense J.D.Carr \& Retief, 141

moggii Exell, 146

molle R.Br: ex G.Don, 146

mossambicense (Klotzsch) Engl., 153

multispicatum Engl. \& Diels, 143

myrtillifolium Engl., 142

nelsonii Dümmer, 140

oblongum F.Hoffm., 142

obtusatum Engl. \& Diels, 146

odontopetalum Engl. \& Diels, 142 omahekae Gilg \& Dinter ex Engl., 147

ondongense Engl. \& Diels, 150

oxystachyum Welw. ex M.A.Lawson, 155

padoides Engl. \& Diels, 148

paniculatum Vent., 154

subsp. microphyllum (Klotzsch) Wickens, 154

parvifolium Dinter, 142

patelliforme Engl. \& Diels, 148

patelliforme Engl. \& Diels p.p.quoad specim., 148

petersii (Klotzsch) Engl., 152

petrophilum Retief, 146

phillipsii Dümmer, 153

platypetalum Welw. ex M.A.Lawson subsp. platypetalum, 155

porphyrolepis Engl. \& Diels, 151

primigenum Marloth ex Engl., 152

prunifolium Engl. \& Diels, 152

psammophilum Diels, 150

psidioides Welw, 147

subsp. dinteri (Schinz) Exell, 147

subsp. grandifolium (F.Hoffm.) Jordaan, 147

subsp. psidioides, 147

subsp. psilophyllum Wickens, 147

quirirense Engl. \& Gilg, 147

ramosissimum Engl. \& Diels, 154

rautanenii Engl. \& Diels, 151

rhodesicum Baker f., 15]

riparium Sond., 139

salicifolium E.Mey. ex Hook., 139

sambesiacum Engl. \& Diels, 151

schinzii Engl. ex Engl. \& Diels, 150

sect.

Angustimarginata Engl. \& Diels, 137

Breviramea Engl. \& Diels, 151

Campestria Engl. \& Diels, 151

Ciliatipetala Engl. \& Diels, 143

Conniventia Engl. \& Diels, 153

Glabripetala Engl. \& Diels, 143

Hypocrateropsis Engl. \& Diels, 147

Macrostigmatea Engl. \& Diels, 142

Megalantherum Exell, 155

Metallicum Exell, 149

Oxystachya Exell, 155

Plumbea Jordaan, A.E.van Wyk \& O.Maurin, 152

Poivrea (Comm. ex DC.) G.Don, 153

Spathulipetala Engl. \& Diels, 141

sonderi Gerrard ex Sond., 139

sp. 2,145

splendens Engl., 146

stevensonii Exell, 152

subgen.

Cacoucia (Aubl.) Exell \& Stace, 152

Combretum, 137

suluense Engl. \& Diels, 150

taborense Engl., 150

tenuipes Engl. \& Diels, 148

ternifolium Engl. \& Diels, 143

tinctorum Welw. ex M.A.Lawson, 142

transvaalense Schinz, 151

var. bolusii Dümmer, 151

var. villosissimum (Engl. \& Diels) Burtt Davy, 151

trichopetalum Engl., 153

truncatum Welw. ex M.A.Lawson, 152

ukambense Engl., 153

undulatum Engl, \& Diels, 143

velutimum DC., 146

vendae A.E.van Wyk, 140

villosissimum (Engl. \& Diels) Engl., 151

wattii Exell, 155

welwitschii Engl. \& Diels, 146

woodii Dümmer, 141

zastrowii Dinter, 155

zeyheri Sond., 141

Conniventia Engl. \& Diels, sect., 153

Dodonaea

caffra Eckl. \& Zeyh., 139

conglomerata Eckl. \& Zeyh., 139

Glabripetala Engl. \& Diels, sect., 143

Hypocrateropsis Engl. \& Diels, sect., 147

Macrostigmatea Engl. \& Diels, sect., 142 
Megalantherum Exell, sect., 155

Metallicum Exell, sect., 149

Oxystachya Exell, sect., 155

Plumbea Jordaan, A.E.van Wyk \& O.Maurin, sect., 152

Poivrea (Comm. ex DC.) G.Don, sect., 153 bracteosa Hochst., 153

mossambicensis Klotzsch, 153

Spathulipetala Engl. \& Diels, sect., 141

Terminalia erythrophylla Burch., 139 